\title{
Spatial statistical analysis applied to rare-element LCT-type pegmatite fields: an original approach to constrain faults- pegmatites-granites relationships
}

\author{
Sarah DEVEAUD ${ }^{1-3^{*}}$, Charles GUMIAUX ${ }^{1-3}$, Eric GLOAGUEN ${ }^{1-3}$, Yannick BRANQUET ${ }^{1-3}$ \\ ${ }^{I}$ BRGM, ISTO, UMR 7327, 3 av. Claude Guillemin, BP 36009, 45060 Orléans, Cedex 2, France; S.Deveaud@brgm.fr \\ ${ }^{2}$ CNRS/ISTO, UMR 7327, 1 A rue de la Férollerie, 45071 Orléans, Cedex 2, France \\ ${ }^{3}$ Université d'Orléans, ISTO, UMR 7327, 1 A rue de la Férollerie, 45071 Orléans, Cedex 2, France \\ * Corresponding author
}

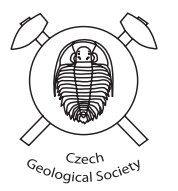

\begin{abstract}
The emplacement of LCT-type (Lithium-Cesium-Tantalum) pegmatite fields and their relationships with host rocks are commonly studied with petrographic, geochemical and isotopic analyses. Although these methods are efficient to understand the process of differentiation and/or enrichment in rare-elements during the crystallization of pegmatites, they are not appropriate to decipher, on field scale, the LCT pegmatites' emplacement. Here we apply a spatial statistical analysis to the LCT-pegmatites field of Monts d'Ambazac in the Saint Sylvestre Granitic Complex (Massif Central, France), in order to constrain and discuss spatial relationships between pegmatites, granites and faults. Various numeric variables (distance to the nearest neighbor, Ripley's L'-function, Euclidean distance, spatial density distribution, cluster analysis) have been computed to quantify both i) the spatial distribution of the pegmatite occurrences, including their grouping/ scattering and aligning features, and ii) the association of the pegmatites with individual rock types or structures. We show that a spatial relationship can be quantified between LCT-type pegmatites and $\sim \mathrm{N}$ to NNE trending faults family; with $50 \%$ of the pegmatite occurrences located less than $500 \mathrm{~m}$ away from one of these faults. This result is confirmed by the spatial relationships between the pegmatites distribution and the highest spatial density of this trend fault class. Moreover we demonstrate the high clustering rate of the pegmatites set. These clusters are preferentially oriented in the same $\mathrm{N} 015^{\circ}$ direction as the trend of the A class-faults, which is parallel to a large sheared corridor described in the central part of the study area. In contrast to analyses on relationships between faults and pegmatites, our results point out a lack of spatial link between each of the pegmatite subtypes and several potential granitic sources. We thus suggest that pegmatites were emplaced along A-faults trend. The development of these faults could have been favored by, and focused in, the central part of the granitic complex beforehand affected by a large shear-zone. These results reveal the efficiency and the utility of such a statistical approach to better constrain the LCT type pegmatites-faults-granites model. We think that such a methodology should be more systematically applied to the exploration of LCT pegmatite fields, particularly in poorly exposed domains.
\end{abstract}

Keywords: spatial statistics, LCT pegmatites field, cluster analysis, Saint Sylvestre Granitic Complex, French Massif Central Received: 22 March 2013; accepted: 14 June 2013; handling editors: D. London/P. Uher

\section{Introduction}

Rare-elements as Tantalum $(\mathrm{Ta})$ and Niobium $(\mathrm{Nb})$ are almost exclusively produced from giant Lithium-Cesium-Tantalum (LCT)-type pegmatites (e.g. Greenbushes, Wodgina, Tanco, Volta Grande; Pollard 1995). Other metals like Beryllium (Be), Cesium (Cs) and Tin ( $\mathrm{Sn}$ ) as well as industrial minerals (i.e. feldspars and quartz used in the production of ceramic) may be valuable by-products of rare-element pegmatite deposits exploitation (e.g. Černý 1992). One specific common feature of pegmatite fields is the clustered distributions of the pegmatites bodies [e.g. among others, Black Hills, South Dakota (Norton and Redden 1990), the Barroso-Alvão, Portugal (Lima 200; Martins 2009), and the Fregenada-Almendra, Salamanca, Spain (Vieira 2010)]. Up to now, studies dedicated to the genesis of LCT-type pegmatites, and to their relationships with the host rocks, were mainly based on mineralogy, petrology, isotope geochemistry (e.g. $\mathrm{Li}, \mathrm{O}$ and $\mathrm{Pb}$ ) and/or geochronology (e.g. U-Pb, $\mathrm{Ar}-\mathrm{Ar}$ methods). Moreover, these studies were focused on peculiar pegmatites (e.g. Tanco, Bernic Lake Manitoba, Stilling et al. 2006; Van Litchervelde 2006) rather than on a whole pegmatite field. Trueman and Černý (1982) and, then, London (2008) proposed a theoretical genetic model highlighting the development of pegmatite fields in magmatic intrusion environments. This model implies that rare-element pegmatites are derived from parental granitic sources with a chemical differentiation favored by two main processes: i) the enrichment in volatile elements (e.g. Li, Be, F) and ii) the increase of the fractionation degree and the enrichment in rare-elements 
(e.g. Li, Be, Rb, Cs, Nb-Ta, Sn...) with respect to the distance from the granitic source. In most cases, the parental magma corresponds to a two-mica leucogranite emplaced during continental collision (Chappell and White 1974; Černý et al. 2005).

This model is actually the most widely used for mining exploration of rare-metals-bearing pegmatites. However, it is noteworthy that several rare-metal pegmatite fields demonstrate neither evident genetic nor spatial association with granitic body (e.g. Göd 1989; Kontak and Kyser 2009; Demartis et al. 2011; Dill et al. 2012). In that case, a major controlling factor of LCT-type pegmatites appears to be the occurrence of regional shear-zones (e.g. Kontak et al. 2005; Dill et al. 2012). Emplacement models are then still matter to debate.

In order to better constrain processes involved in the development of LCT-type pegmatite fields, a first step is to characterize the spatial relationships between pegmatite bodies and surrounding structures and units. In this paper, we develop a spatial statistical approach applied to the LCT-pegmatite field of Monts d'Ambazac, located in the Saint Sylvestre Granitic Complex (SSGC, Massif Central, France, Raimbault 1998). Indeed, the use of spatial analysis techniques, with the computation of various numeric variables (e.g. distance to the nearest neighbor, Ripley's L'-function, Euclidean distance, spatial density distribution, cluster analysis), allows quantifying both: i) the spatial distribution of the pegmatite bodies, including their grouping/scattering and aligning features, and ii) the overlap or proximity of the pegmatites with given rock types or structures (ductile shear zones, fault families, granite units). In order to highlight any potential spatial link between pegmatites and the surrounding structures $s$. $l$, one must bring out abnormal spatial distributions of the pegmatites with regard to the cartographic outlines. Thanks to a good quality of the data sets, the Variscan Monts d'Ambazac pegmatite field constitutes an excellent case study to test such spatial statistics. It has the potential to constrain, in particular, the spatial relationships between recognized LCT-type pegmatites and the hosting granites and fault zones. Data sources have included published papers, geological maps and unpublished PhD theses, taking benefit from uraniferous mining works throughout the study area (La Crouzille district, Fig. 1b; e.g. Friedrich et al. 1987; Cathelineau et al. 1990; Cuney et al. 1990). Various data sets have been homogenized and compiled in a Geographic Information System (GIS). Spatial statistics has been undertaken in order to test: i) the spatial proximity between pegmatites and faults trace, ii) the overlapping between high fault-density areas and pegmatite bodies, iii) the spatial proximity between pegmatites and faults intersections, and iv) the spatial proximity and overlapping of the pegmatites with host-granites. Finally, cluster analysis of the pegmatite bodies is performed in order to map automatically the spatial average extension of each cluster and to compare their location and trend (i.e. the preferred strike alignment of the pegmatites) to the ones of the faults sets. Results of the statistical tests are further interpreted and discussed in terms of potential genetic links between pegmatites and various geological structures.

\section{Geological setting and field observations}

\subsection{The Saint Sylvestre Granitic Complex}

The Saint Sylvestre Granitic Complex (SSGC) is located in the northern part of the French Massif Central, and was emplaced during the Variscan orogeny at $324 \pm 4 \mathrm{Ma}$ (cf. Brâme-Saint Sylvestre facies; Holliger et al. 1986) during a regional NW-SE extension (Faure and Pons 1991). The 3-D geometry of the SSGC (Audrain et al. 1989) is a thin laccolith of $2-3 \mathrm{~km}$ in thickness which intruded both the paraautochton and the allochthonous lower gneiss units (Fig. 1a). The SSGC is bounded by the Nantiat normal fault (Floc'h 1983) and by the Arrènes-Ouzilly dextral shear zone (Mollier and Lespinasse 1985) on its western and eastern edges, respectively. Besides, the granitic complex is crosscut by a $5 \mathrm{~km}$ wide, on average $\mathrm{N} 20^{\circ} \mathrm{E}$ trending sheared corridor (Fig. 1a-b; Mollier and Bouchez 1982; Mollier and Lespinasse 1985; Cuney et al. 1990; Hottin et al. 1995). Based on magmatic foliations trends, these authors recognized that deformation occurred - at least partially - during granite emplacement. Besides, a well-developed network of $\mathrm{N} 020^{\circ} \mathrm{E}$-trending brittle faults has also been described in this particular area (e.g. Cathelineau et al. 1990; Cuney et al. 1990; Scaillet et al. 1996).

This peraluminous complex, which was derived by melting of continental crustal components (e.g. Vidal et al. 1984), is composed of three main granitic facies resulting from successive magma injection, from west to east, following this temporal sequence: 1) Brâme, 2) $\gamma 1$ Saint Sylvestre and 3) Saint Goussaud (see Fig. 1; e.g. Cuney et al. 1990; Scaillet et al. 1996). These three main granite bodies are crosscut by various plugs of granites. The Brâme granite is crosscut by Châteauponsac granite plugs, dykes and sills. The Saint Sylvestre $\gamma 1$ granite is composed of two sub-facies $(\gamma 1 \mathrm{a}$ and $\gamma 1 \mathrm{~b})$, based on granite grain size and on a slight difference of $\mathrm{K}$-feldspar proportion. The $\gamma 1$ granite is crosscut by both the $\gamma 2 \mathrm{Fa}$ nay and $\gamma 3$ Les Sagnes granite plugs, sills and dykes (Fig. 1b, Cuney et al. 1990). The $\gamma 2$ and $\gamma 3$ fine- to mediumgrained granitic stocks were emplaced at 310-300 Ma (Cuney et al. 1990). These small granitic cupolas are more peraluminous, fractionated and enriched in some incompatible elements (e.g. U, Li) than $\gamma 1$-coarse grained 


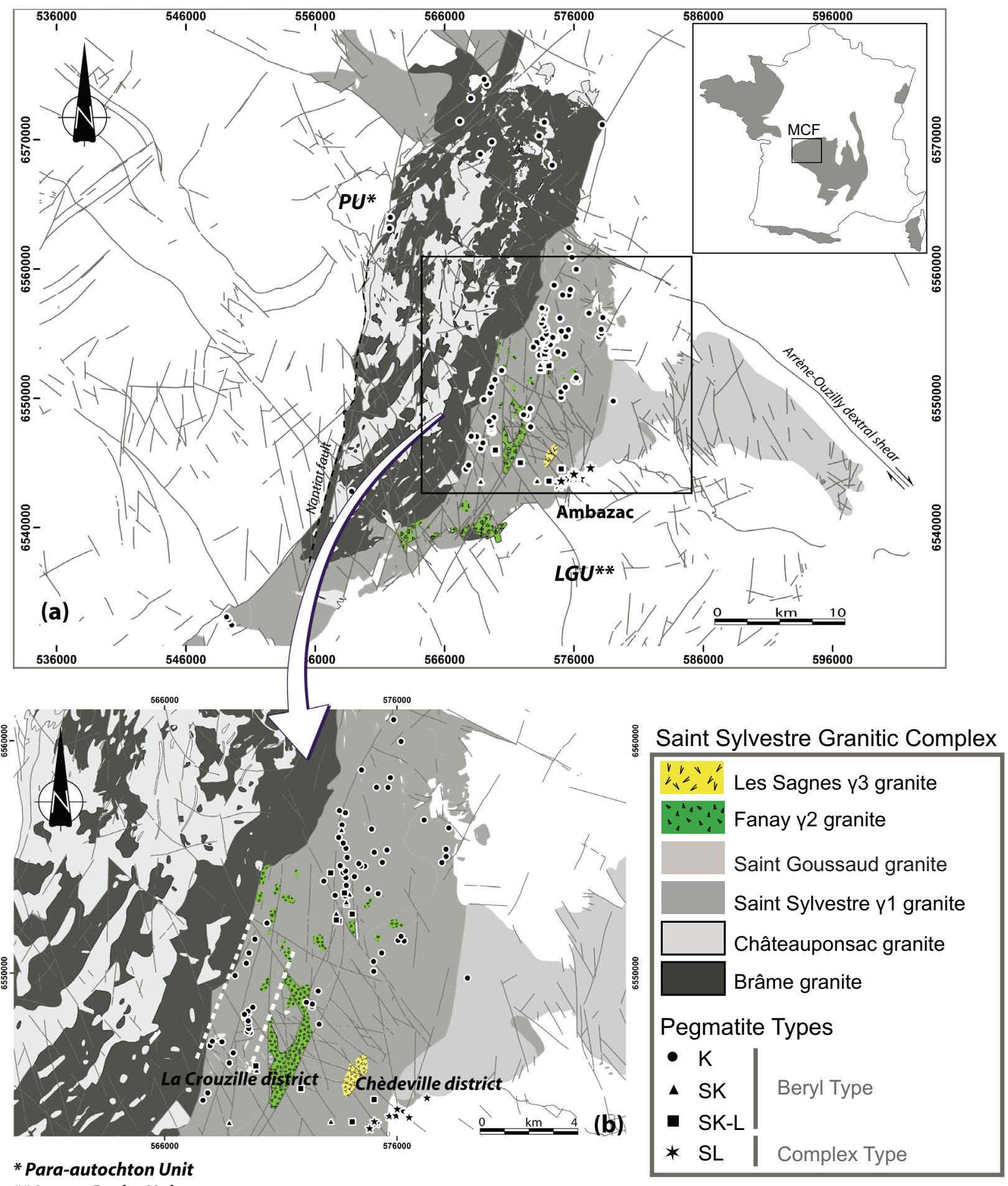

** Lower Gneiss Unit

Fig. 1a - Geological map of Saint Sylvestre Granitic Complex (SSGC) and localization of the recognized pegmatites. White dotted lines illustrate the large sheared-corridor (e.g. Mollier and Bouchez 1982; Mollier and Lespinasse 1985; Cuney et al. 1990; Hottin et al. 1995). b - Zoom on Monts d'Ambazac pegmatite field and the $\gamma 2$ Fanay and $\gamma 3$ Les Sagnes granitic injections located in this part of the Saint Sylvestre granite.

granite (Cuney et al. 1990). These differences are also observed in mineralogy: the $\gamma 1$ is composed of biotite and muscovite, $\mathrm{K}$-feldspars and residual sillimanite; $\gamma 2$ is made of residual biotite, muscovite, K-feldspar, albite and quartz; $\gamma 3$ is composed of muscovite, albite and quartz. The $\gamma 3$ leucogranite is considered as the ultimate highly differentiated magmatic injection of the SSGC, enriched in U, Li, F and Sn (Cuney et al. 1990; Raimbault 1998). 


\subsection{The Monts d'Ambazac rare-element pegmatite field}

The Monts d'Ambazac rare-element pegmatite field - at least partly - belongs to the same rare-element magmatism event as the two $\mathrm{Li}-\mathrm{Be}-\mathrm{Nb}-\mathrm{Ta}-\mathrm{Sn}$-enriched leucogranites of Beauvoir (Allier; Aubert 1969; Cuney et al. 1992) and Montebras (Creuse; Aubert 1969) as well as the Richemont rhyolitic dyke (Raimbault and Burnol 1998). All these magmatic bodies belong to a rareelement magmatic belt extending through the northern border of the French Massif Central (e.g. Marignac and Cuney 1999). Indeed, the Monts d'Ambazac rare-element pegmatite field emplacement overlapped in age the rareelement magmatism event (c. $310 \mathrm{Ma}$, Cuney et al. 2002) since the more differentiated pegmatites (e.g. Chèdeville district, Fig. 1b) have been dated at $309 \pm 0.9 \mathrm{Ma}$ (Cheilletz et al. 1992). Furthermore, geochemical composition of the Monts d'Ambazac pegmatites is similar to the one of the above-mentioned granites (Raimbault 1998).

With the exception of a few rare-element pegmatites of the Chèdeville district, hosted in the parautochthonous metamorphic unit (Raimbault 1998, Fig. 1b), the raremetal pegmatites of Monts d'Ambazac are all confined into the coarse-grained $\gamma 1$ granite (Fig. 1a). During fieldwork, 21 plane measurements of the pegmatite- $\gamma 1$ granite contact from 16 distinct occurrences (Fig. 2a) were obtained. They show a mean strike of N015 $\pm 16^{\circ}$ and a $40-50^{\circ}$ SE dip on average (Fig. 2a-b). A detailed typology (internal structure, mineralogy, strike and dip) of the Monts d'Ambazac pegmatites field has been performed from a classification published by Burnol (1974), complemented by our own observations. This classification is based on pegmatite/aplite ratio, with mineralogical and geochemical features of pegmatites and it permits to distinguish four distinct types: i) on a scale of one $\mathrm{cm}$ to one $\mathrm{m}$ K-rich pegmatites type $(\mathrm{K})$ devoid of aplitic units, ii) on a scale of ten $\mathrm{m} \mathrm{Na-K}$ pegmatites type with scattered fine aplites (SK), iii) on a scale of several tens of $\mathrm{m} \mathrm{Na}-\mathrm{K}$ with late $\mathrm{Na}-\mathrm{Li}$ phase aplite-pegmatites type with one or more $m$ layered aplitic units (SK-L) and finally iv) on a scale of ten $\mathrm{m} \mathrm{Na-Li} \mathrm{aplite-pegmatite}$ type (SL) with similar proportions of aplites and pegmatites forming dykes (i.e. sharp and planar contact with the host granite). Based on a combination of available geochemical and petrological data (e.g. Perrier 1962; Patureau 1982; Raimbault 1998) with new observations, and using the Černý and Ercit' s typology (2005), these can be classified as follows: i) type $\mathrm{K}$ is equivalent to Beryl-Columbite subtype, ii) type SK is an intermediate equivalent between Beryl-Columbite and Beryl-Columbite-Phosphates subtypes, iii) type SK-L is equivalent to Beryl-Columbite-Phosphates subtype and iv) type SL is equivalent to lepidolite subtype. Pegmatites of the Beryl type are mainly composed of quartz, K-feldspar, albite, muscovite, \pm biotite and beryl. A great diversity of accessories, dominated by phosphate minerals, has been observed including: apatite, triplite, amblygonite, cassiterite, columbite, tantalite, Li-muscovite, lepidolite and zinnwaldite (e.g. Perrier 1962; Patureau 1982; Raimbault 1998; Collective 2008). Even though most of these pegmatites belong to the Beryl-Columbite subtype (K), some are of the Beryl-Columbite-Phosphate subtype (SK-L), and others (SK) appear as intermediate between the two, containing scarce phosphates. Pegmatites of the Complex type occur only in the Chèdeville district (Fig. 1b) and are mainly composed of quartz, albite, petalite, lepidolite, and scarce K-feldspar. Accessory minerals from this type are mainly represented by apatite, cassiterite, columbite, tantalite, topaz, amblygonite, montebrasite, monazite, niobium rutile and rubellite (Raimbault 1998).

The above detailed classification introduces more details concerning the internal structures and the fractionation degree of pegmatites than that of Černý and Ercit (2005) and the four classes will be used in the following text for the spatial statistical analysis.

\section{Spatial distribution analysis of pegmatites}

In this study, 118 occurrences of pegmatites have been compiled from all publications and data sources available on the Monts d'Ambazac pegmatite field (e.g. Perrier 1962; Burnol 1974; Patureau 1982; Fig. 1a). This data base was complemented by our own field data. For each pegmatite occurrence found, projected coordinate values (RGF93 datum - Lambert Conformal Conic projection) are stored in a GIS database with information on mineralogical content, the class (following the above described typology), strike and dip of pegmatite- $\gamma 1$ granite contact (Fig. 2), when measured, and a reference to the data source. More precisely, the pegmatites set is composed of 96 pegmatites belonging to the type K, 4 SK, 8 SK-L and 10 SL-type pegmatites (Fig. 1a-b). The bounding box which includes the SSGC outline, extents $50 \mathrm{~km} \mathrm{~N}-\mathrm{S}$ and $16.5 \mathrm{~km} \mathrm{~W}-\mathrm{E}$ (Fig. 1a). Thus, a rectangular area of 825 $\mathrm{km}^{2}$ is used in this study as a reference for the calculation of all spatial statistical parameters.

Several methods have been proposed for analyzing the spatial pattern of point sets with applications to Earth sciences including Fry analysis (Fry 1979) and fractal analysis (Carranza 2009a and references therein). In order to characterize and quantify the overall spatial distribution of the pegmatite occurrences throughout the study area, an alternative method, the Distance to Nearest Neighbor (DNN) has been used here. This statistical technique, developed by Clark and Evans (1954), allows measuring spatial relationships in populations and is ap- 
plied to various research topics such as, among others, mining exploration (e.g. Carranza 2009b; Mamuse et al. 2010), geomorphology (e.g. Wilkins and Ford 2007), volcanology (e.g. Bleacher et al. 2009), planetology (e.g. Baloga et al. 2007), urban systems analysis (e.g. Eckley and Curtin 2013) or ecology/epidemiology (e.g. Larkin et al. 1994; Haase 1995). Euclidean distance is computed - in 2D map view - between each point and its closest neighboring distinct one, giving the DNN value.

Analysis of the frequency distribution of the computed DNN for the 118 pegmatite occurrences (Fig. 3a), shows a minimum of $15 \mathrm{~m}$ and a maximum distance of $4475 \mathrm{~m}$. Both the relative and the cumulative frequency curves highlight strong asymmetrical distributions (with a positive skewness of 3.46); the observed average DNN value is $528 \mathrm{~m}$ and median equals $367 \mathrm{~m}$. Following Clark and Evans (1954), the R ratio value gives an index measure of the spatial distribution of objects in a map, as follows:

$$
\mathrm{R}=\frac{\overline{r_{O}}}{\overline{r_{E}}}
$$

where $\overline{r_{O}}$ is the observed average DNN value $(528 \mathrm{~m}$ here) and $\overline{r_{E}}$ average DNN value as expected for a purely random spatial distribution with:

$$
\overline{\mathrm{r}_{\mathrm{E}}}=\frac{1}{2 \sqrt{\rho}}
$$

$\rho$ being the point density across the study area (expressed as a number of objects per unit of area; see Clark and Evans 1954 for details). The $\mathrm{R}$ index value has a limited range (Fig. 3b) from 0 , which corresponds to an extreme clustering where all data points are located at the same place, to a maximum of 2.1491 for points distributed in an even and hexagonal pattern. A purely random distribution of the points set corresponds to R of unity (Fig. 3b). Here, the observed average DNN $(528 \mathrm{~m})$ is clearly less than the expected value (1464 m; Fig. $3 a)$. The calculated $R$ value of 0.36 (Fig. 3b) proves the high clustering degree of the pegmatite occurrences throughout the Monts d'Ambazac field (i.e. data points are about three times closer to each other than expected for a randomly distributed set with the same number of points).

Fig. 2a - Stereographic projection of 21 pegmatites strikes measured during field campaign from 16 pegmatite occurrences. $\mathbf{b}-$ Distribution of the strikes. The main direction corresponds to $\mathrm{N} 015 \pm 16^{\circ}(2 \sigma)$.
The Ripley's K-function (Ripley 1977) and its derivatives is another available statistical tool used to identify and understand the pattern of map distribution of observations (more precisely, it highlights deviations from spatial random distribution of objects). Complementary to the DNN analysis, this function allows describing the degree of clustering or scattering of elements on various scales and it has been used extensively, for instance in biology (e.g. Kiskowski et al. 2009; Rozas et al. 2009). Ripley's K-function expresses the average number of neighboring points lying at a maximum distance $r$ from data points divided by the overall point density, as follows:

$$
\mathrm{K}(\mathrm{r})=\frac{1}{\mathrm{n}} \sum_{\mathrm{i}=1}^{\mathrm{n}} \mathrm{N}_{\mathrm{i}}(\mathrm{r}) / \rho
$$

with $n$ the total number of points, $N_{i}(r)$ the number of points within a neighboring distance $r$ of the $i$ point from the data set and $\rho$ is the overall point density value.

Situations on various scales are thus explored with changing $\mathrm{r}$ in the function (Fig. 3c). In the same way, the theoretical value of this function for a fully random spatial distribution is $\pi r^{2}$ and the first derivative of the $\mathrm{K}$-function is:

$$
\mathrm{L}(\mathrm{r})=\sqrt{\mathrm{K}(\mathrm{r}) / \pi}
$$

Finally, the second derivative (L') of the function is determined in order to fix a zero value for the reference random distribution (Fig. 3c):

$$
L^{\prime}(r)=L(r)-r
$$
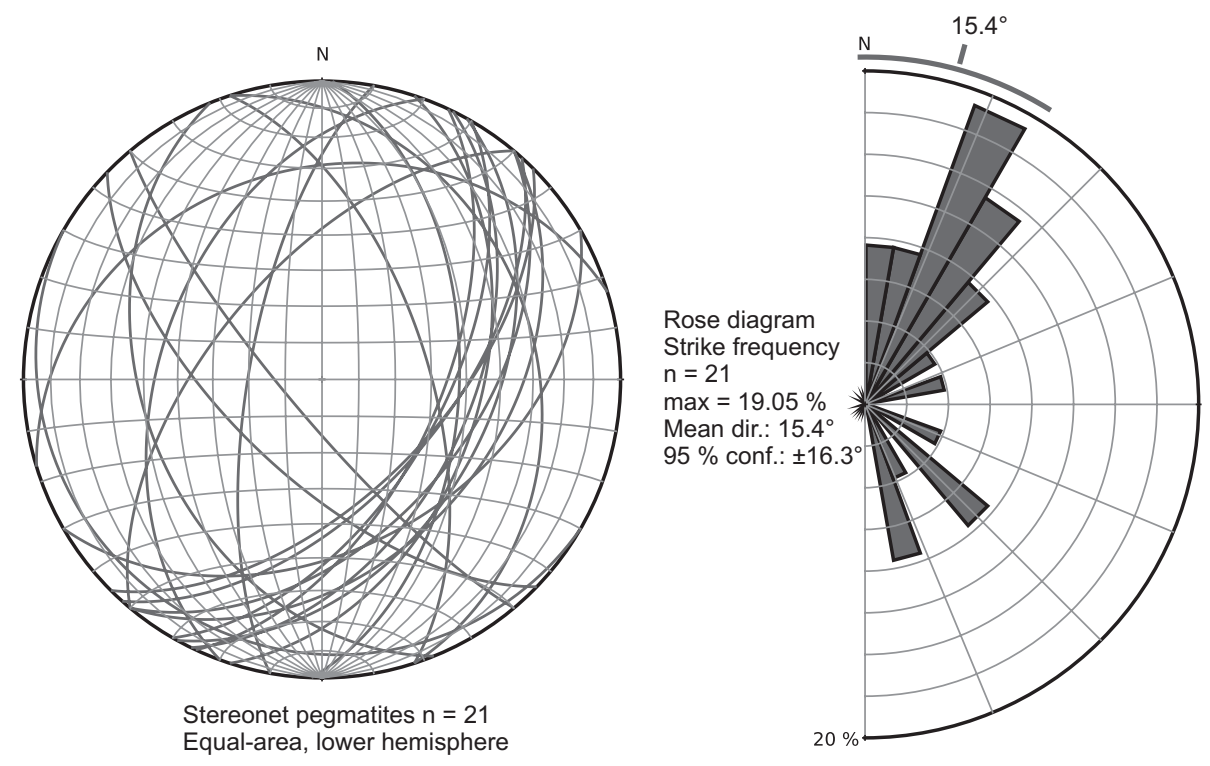
Ripley's L'-function thus facilitates the interpretations of the various distribution patterns for different scales (see arrows in Fig. 3c): constant values correspond to a constant random distribution of the points on the scales considered. Increasing Ripley's L'-function describes a

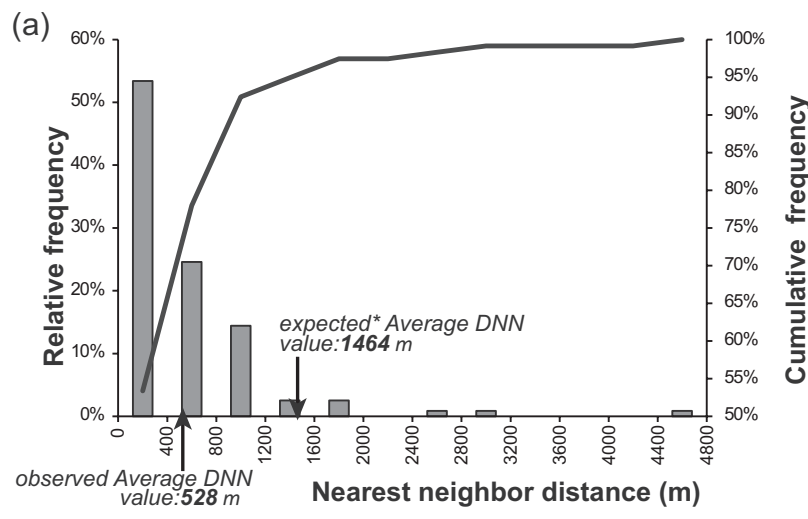

(b) $\quad \mathbf{R}$ ratio $=$ observed average $\mathrm{DNN} /$ expected $^{*}$ average DNN
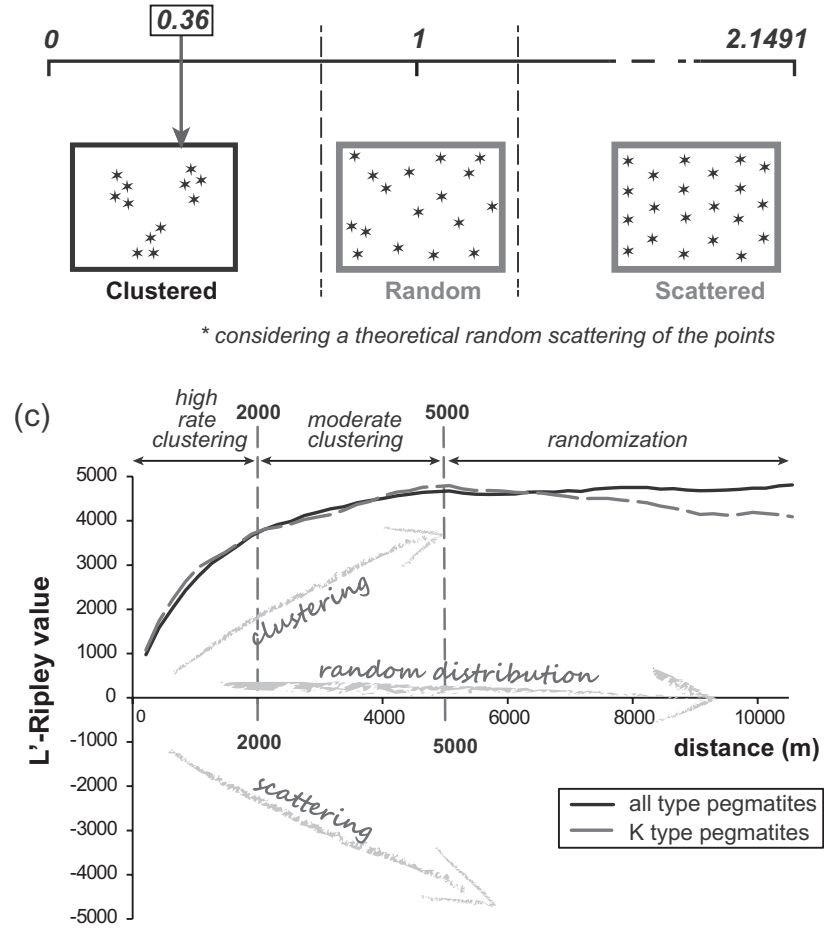

Fig. 3a - Relative and cumulative frequency distributions of the Distance Nearest Neighbor (DNN) for the 118 pegmatites considered in the whole SSGC; the $400 \mathrm{~m}$ bin size of the histogram ranges is fixed following the Sturges's law (Sturges 1926). b - Ratio (R; (1)) computed from the observed average DNN value over the expected* average $\mathrm{DNN}$ value (2). The calculated $\mathrm{R}$ value of 0.36 highlights the high clustering rate of the pegmatites throughout the SSGC. $\mathbf{c}-$ Ripley's L'function (5) computed to detect spatial deviations from a homogenous Poisson distribution (i.e. Ripley's L'-function value $=0$ ). The computed Ripley's L'-function value $=3700 \mathrm{~m}$ corresponds to a high clustering rate of the pegmatites distribution, with a clustering distance of 2000 $\mathrm{m}$ and Ripley's L'-function value $=4500 \mathrm{~m}$ for a maximum reference distance (see MRD, Allanic and Gumiaux, 2013) equal to $5000 \mathrm{~m}$. See text for further explanation. clustering distribution of the points set and, conversely, decreasing values correspond to a scattering distribution of the points. Furthermore, the slope of the function is proportional to the rate of clustering/scattering for a given scale (i.e. a given maximum neighboring distance; Fig. $3 c)$. Here, the computed L' function increases with distance (i.e. with decreasing scale) and stabilizes (at 4500 $\mathrm{m}$ ) after $\mathrm{r}=5000 \mathrm{~m}$; this shows a persistent clustering of the pegmatite occurrences up to $5000 \mathrm{~m}$ and a randomization of the dispersion of these clustered points beyond $5000 \mathrm{~m}$. Note that both curves corresponding to the L'function for all pegmatites and for the K-type ones are superimposed (Fig. 3c). In the clustering distance range $(0-5000 \mathrm{~m})$ two clustering rates are distinguished based on slope breaks of the curve: a high clustering rate up to $2000 \mathrm{~m}$ and a moderate one from 2000 to $5000 \mathrm{~m}$. Following Allanic and Gumiaux (2013), these distances can thus be used to separate the points set in groups and to map clusters (see Maximum Reference Distance (MRD) Allanic and Gumiaux, 2013). Both results obtained from the DNN analysis and from the Ripley's L'-function computations are consistent with the $\mathrm{R}$ ratio value and clearly show that the pegmatites are highly clustered throughout the Monts d'Ambazac district and that clustering occurs on all scales up to $5000 \mathrm{~m}$ (with no scattering even expressed). This high clustering rate suggests that a strong control of the lithologies and/or structures exists on the locations where pegmatites were emplaced. A spatial statistical approach is thereafter developed in order to highlight such potential relationships.

\section{The pegmatites-host lithologies- structures spatial relationships}

In the Monts d'Ambazac area, some of the old underground works are exceptionally well preserved, which facilitate mineralogical and petrological studies within the pegmatitic bodies (including the 3D description of pegmatites' internal zoning). In contrast, systematic structural analysis is difficult as the footwall and hanging wall of the pegmatites are most often not outcropping or were destroyed by the past artisanal and small-scale mining activity. From the 118 occurrences as referenced from old works and literature, only 16 can currently be the subject of structural measurements (Fig. 2). Thus, in order to discuss the potential structural control on pegmatite field genesis, we propose to focus on regional scale, on the spatial relationships between the pegmatite occurrences and the geological structures. Here each segment is defined by its trend (or strike), but it does not contain any other information such as kinetic or dip characteristics. As shown below, various spatial statistical parameters can be computed from the layers of the GIS database 
including points set (pegmatites location), lines (faults and shear zones) and polygons (mapped geological units).

\subsection{Methodology}

\subsubsection{Choice of analyses}

Several methodologies have already been developed and proposed for prospectivity mapping using GIS (Knox-Robinson and Groves 1997; Bonham-Carter 2002; Carranza 2009b and references therein). The classical methods used include Boolean methods, weight of evidence scores estimation and fuzzy logic approach (Bonham-Carter 2002), or algebraic methods (e.g. Siris, Vaillant et al. 1995). All these approaches have the same objective to integrate cartographic information from various sources in order to locate zones with high exploration potential or presenting a significant risk level (e.g. natural hazards). Recent applications of such approach have been made for, among others, mining exploration (e.g. Cassard et al. 2008; Feltrin 2008; Carranza 2009a; Porwal et al. 2010), water spring mapping (e.g. Corsini et al. 2009), or biology (e.g. Knudby et al. 2010).

Here, we focus on the analysis of spatial associations among the geological entities, in particular between the pegmatites and the host lithologies and surrounding structures. Indeed, if considering the outlines of different geological objects on a map (i.e. point data, lines such as faults or shear zones, polygons representing geological units) one could roughly establish the potential spatial links between objects by visually determining location correspondences. However, some cartographic configurations are tricky to be objectively analyzed and problems also arise when one wants to quantify the relative control of each type of geological objects on the locations where deposits are emplaced. The use of spatial analysis techniques permits to quantify the spatial links between deposits and geological cartographic structure s. l. (e.g. Carranza 2009a). Some of the classic spatial statistical tests that can be used include: i) frequency analysis of the shortest distance measured between faults or shear zones (lines) and deposits (points), ii) frequency analysis of the shortest distance measured between intersections of the faults (points) and deposits (points), iii) frequency analysis of the faults (or shear-zone) spatial density at location of the individual deposits, iv) frequency analysis of the shortest distance measured between geological unit boundaries (lines) and deposits (points), and v) frequency analysis of crosscutting relationships between the different types of geological units (polygons) and deposits (points). Techniques for the analysis of the distance frequency distribution, quantifying spatial associations between objects, have already been formalized and applied (Berman 1977, 1986; Bonham-Carter 1985;
Carranza and Hale 2002). Following such approach and for each test, the frequency distribution of the computed parameters is analyzed in order to bring out any potential control of the object considered on the spatial distribution of the pegmatites; this is illustrated in the rather simple synthetic example.

\subsubsection{A synthetic case study}

Let's consider the schematic geological map as displayed in Fig. 4a: 15 points (representing deposits) are dispersed over 4 distinct types of polygons (lithological units) and a set of lines (fault segments). As for our natural case, synthetic segments are only defined by their trends; details such as kinetic or dip parameters are not indicated. In order to study the deposits/faults spatial relationships, the Euclidian distance is computed between each point and its closest line segment (Fig. 4a). The frequency analysis of these 15 resulting values (sampled distribution) shows that $\sim 50 \%$ of the deposits are within the two first distance classes from a fault (see black bars histogram; Fig. 4b) and this would argue for a control of the fault set on the deposits location and, hence, on their development.

Now we can introduce a set of points evenly distributed over the map. As previously, the Euclidian distance is computed between each point of this new set and the closest fault segment. As points are scattered over the study area, the resulting histogram (see grey bars histogram; Fig. 4b) corresponds to the frequency distribution of faults" proximity distance for "any" given location of the map and is here defined as the reference distribution. It turns out, from this example, that the frequency distribution computed for the deposits does not deviate too much from the reference one. Indeed, frequency values from the two distributions show similar values (less than $\pm 20 \%$ of difference; Fig. $4 \mathrm{~b}$ ); in other words, the sampled distribution for the deposits can be regarded as a Normal Distribution (ND; i.e. showing no anomaly) for the overall classes (Fig. 4b). Thus, in this synthetic example, deposits are statistically not located any closer to the faults set than any given point of the study area. Thus it must be concluded that faults exercise no control on the locations where deposits developed.

In order to study the spatial relationships of deposits/ lithological units, one possible technique simply consists in counting the points overlapping polygons of one given type (Fig. 4a) which yields to a discrete-data type histogram with, for the example considered, four classes corresponding to the four unit types (Fig. 4c). Here, it would turn out from the analysis of the frequency distribution alone that the lithological unit $A$ contains the majority of the mineral deposits and would have thus controlled, in one way or the other, their development (Fig. 4c). However, comparison of the two histograms shows that the 


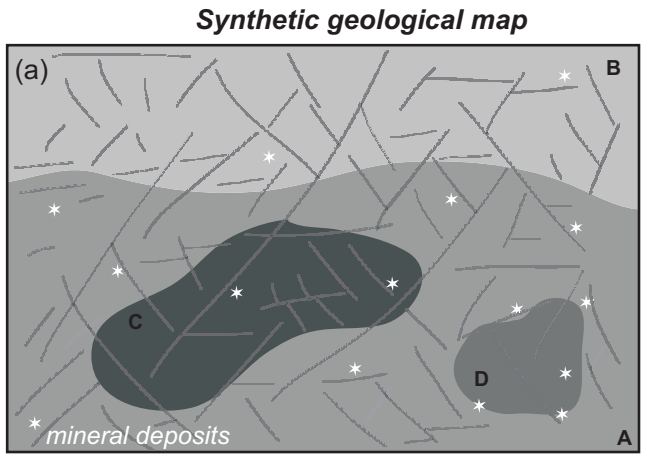

(b)

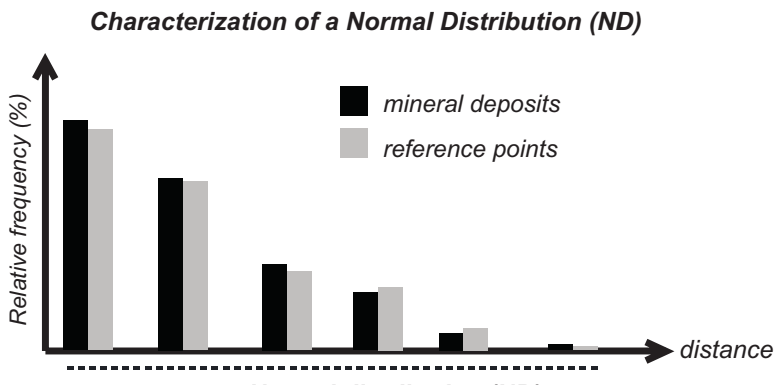

Normal distribution (ND) (c)

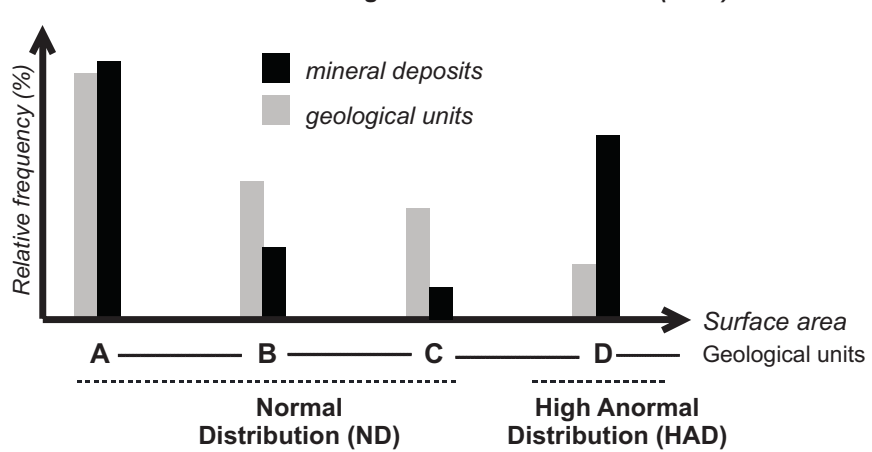

Fig. 4a - In order to illustrate the histogram analysis, a synthetic case is presented corresponding to a geological map with the four lithological units (A, B, C and D), associated with the deposits points set (white stars) and faults set. b - Theoretical Normal Distribution (ND) observed when any spatial anomaly is highlighted between deposits and any geological objects (lithological units, faults). c - Frequency value of deposits relative to the surface area of each lithological unit. A Normal Distribution (ND) is observed when pegmatites frequency values are similar to, or lower than, the reference distribution (see grey bars), and a High Abnormal Distribution (HAD) is highlighted when the pegmatites frequency value rises as the surface area of lithological units decreases.

three first A, B and C lithological types display similar or even less sampled frequency values than the reference one (here computed as the relative surface areas of the polygons; Fig. 4a, c). Here again, the compared frequency analysis highlights that the three lithologies (A, $\mathrm{B}, \mathrm{C}$ ) have no apparent control on the locations where deposits developed. In contrast, the fourth (D) class shows a significantly higher sampled frequency value than the reference one (Fig. 4c); i.e. $33 \%$ of the overall mineral deposits are located in the polygon type representing only $10 \%$ of the whole surface of geological map (Fig. 4a, c). Thereby it appears that the lithological unit D clearly controls the emplacement of deposits.

This simple synthetic example shows that the frequency distribution analysis of a given statistical parameter sampled solely at the deposit locations (here named sampled distribution) is not sufficient as such to disclose spatial correlations between the points of interest (deposits) and other geological objects. For each spatial statistical tool used, one must compare this sampled distribution to the one corresponding to any given point of the study area: the reference distribution. Techniques have been proposed to compare observed distributions with reference ones (e.g. Bonham-Carter 1985; Carranza 2009a).
In this study we define a classification, for a given class of a frequency distribution a Normal Distribution (of the pegmatites) $N D$ for a sampled to reference distribution ratio < 1.2, Low Abnormal Distribution (LAD) for a ratio within the range $[1.2 ; 1.5[$ and High Abnormal Distribution (HAD) for a ratio value $\geq 1.5$. As an example, the pegmatites frequency divided by the lithology D frequency in Fig. $5 \mathrm{c}$ would give a ratio of $\sim 2.2$. In the following section, this approach is applied and tested on the case of the Monts d'Ambazac pegmatites field.

\subsection{Data used}

Two supplementary data sets are integrated in the GIS database: polygons displaying the spatial extent of lithological units across the area and lines representing mapped faults. After compilation of the data, all sets have been homogenized in a common Lambert Conformal Conic projection ( $R G F 93$ datum) to insure the precision required for spatial statistics calculation.

Geological boundaries of the lithological units are extracted from the geological map of France 1:50 000 (Arène et al. 1972; Flageollet et al. 1974; Hottin et al. 


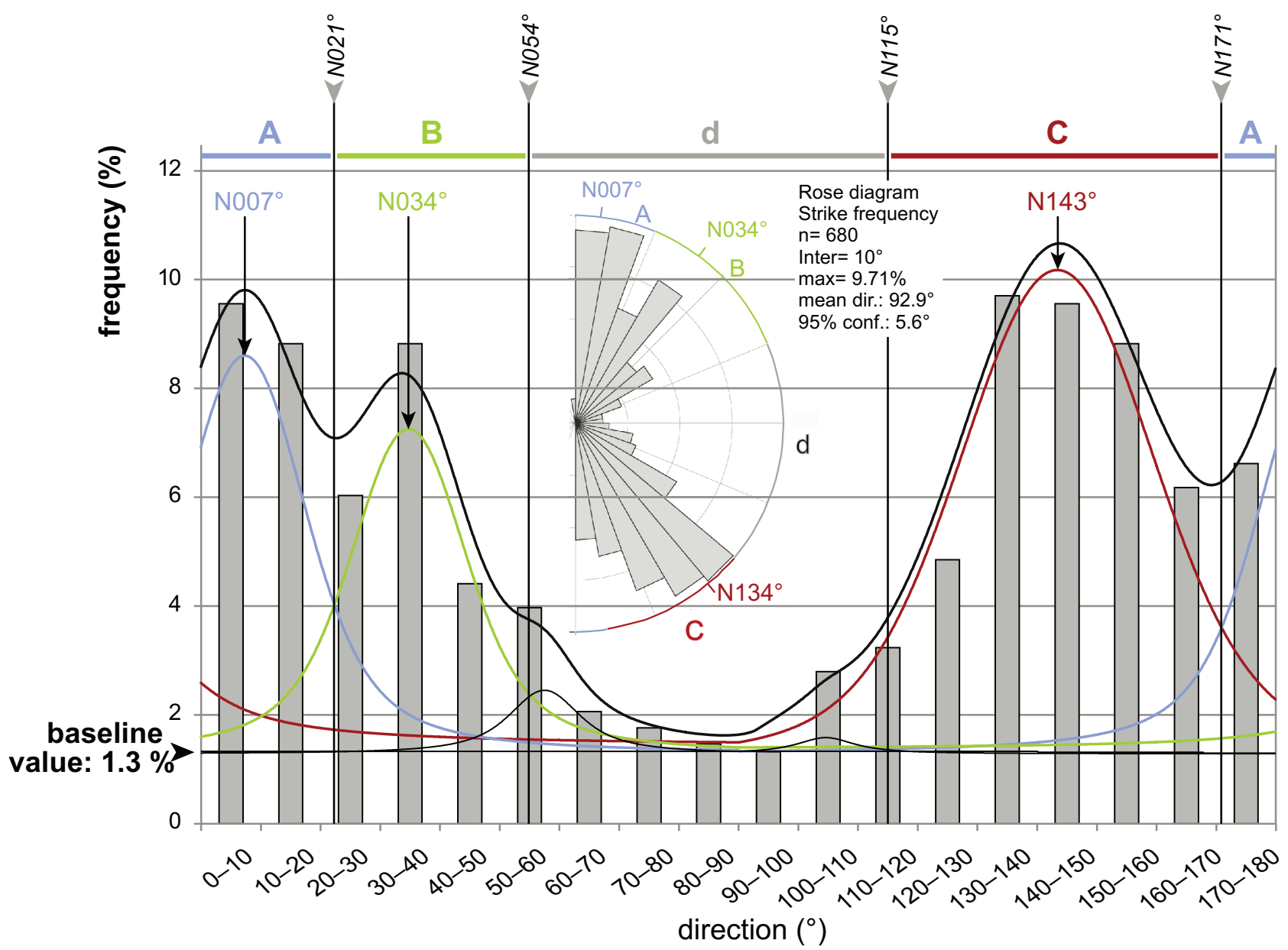

Fig. 5 Domainal distribution of 680 extracted fault strike values in the SSGC. Rose diagram illustrates the same fault strike distribution in the $\mathrm{N} 0-\mathrm{N} 180^{\circ}$ range.

1995). As described above, the pegmatites quasi exclusively occupy the $\gamma 2$ and $\gamma 3$ granitic facies of the complex. The $\gamma 2$ granitic facies crops out at several separate locations in the SSGC while the $\gamma 3$ granitic facies is represented by a single polygon (Fig. 1b). These units correspond to an area of $14 \mathrm{~km}^{2}$ (surface integrated in that case) and $1.13 \mathrm{~km}^{2}$, respectively (Fig. 1a-b).

The faults set is also compiled from the geological map of France 1:50 000 (the same sheets as above). For each fault, attribute information is given on its nature, strike and reference of the data source. This faults set is composed of 680 segments which represent a total cumulated length of $24.4 \mathrm{~km}$. Analysis of the faults trend shows clear preferred directions, in both the NNE and SE quadrants, with multimodal distributions (see rose diagram in Fig. 5). Best-fit decomposition of the frequency distribution has been computed with Lorentzian type functions and a rather low base level value of $1.3 \%$ (which would represent the noise in the strikes of the faults set). The rest of the distribution can almost entirely be decomposed in three faults strike families (Fig. 5): i) class family $A$ from $\mathrm{N} 171^{\circ}$ to $\mathrm{N} 021^{\circ}$ (including $\mathrm{N} 0^{\circ}$ as directional data are of circular type) and a maximum at $\mathrm{N} 007^{\circ}$, ii) class family $B$ from $\mathrm{N} 021^{\circ}$ to $\mathrm{N} 054^{\circ}\left(\max . \mathrm{N} 034^{\circ}\right)$ and iii) class family $C$, the most represented one, from $\mathrm{N} 115^{\circ}$ to $\mathrm{N} 171^{\circ}$ (max. $\mathrm{N} 143^{\circ}$ ). These direction families are further treated as three distinct populations of faults in some of the computations. The fault-strikes corresponding to the $\mathrm{N} 054^{\circ} \mathrm{E}$ to $\mathrm{N} 121^{\circ} \mathrm{E}$ range $(d)$ display classes with the frequency value of the computed baseline (1.3\%). The corresponding faults are thus regarded not to belong to any particular family or tectonic event but to the noise level of the data set. Faults of that strike range are thus not considered as a particular class family in the statistical analysis.

In this study, two types of computation methods have been used to extract statistical parameters, distance-based (Euclidean distance) and density-based (Kernel estimation; see Silverman 1986). As detailed below, four spatial statistical tests are performed and frequency analyses are applied to: i) the shortest distance value between pegmatites and faults, ii) the shortest distance between each type of pegmatites and the hosting- $\gamma 2$ and $\gamma 3$ granitic facies, iii) the distance between pegmatites and faults' intersections and iv) the faults' spatial density. 


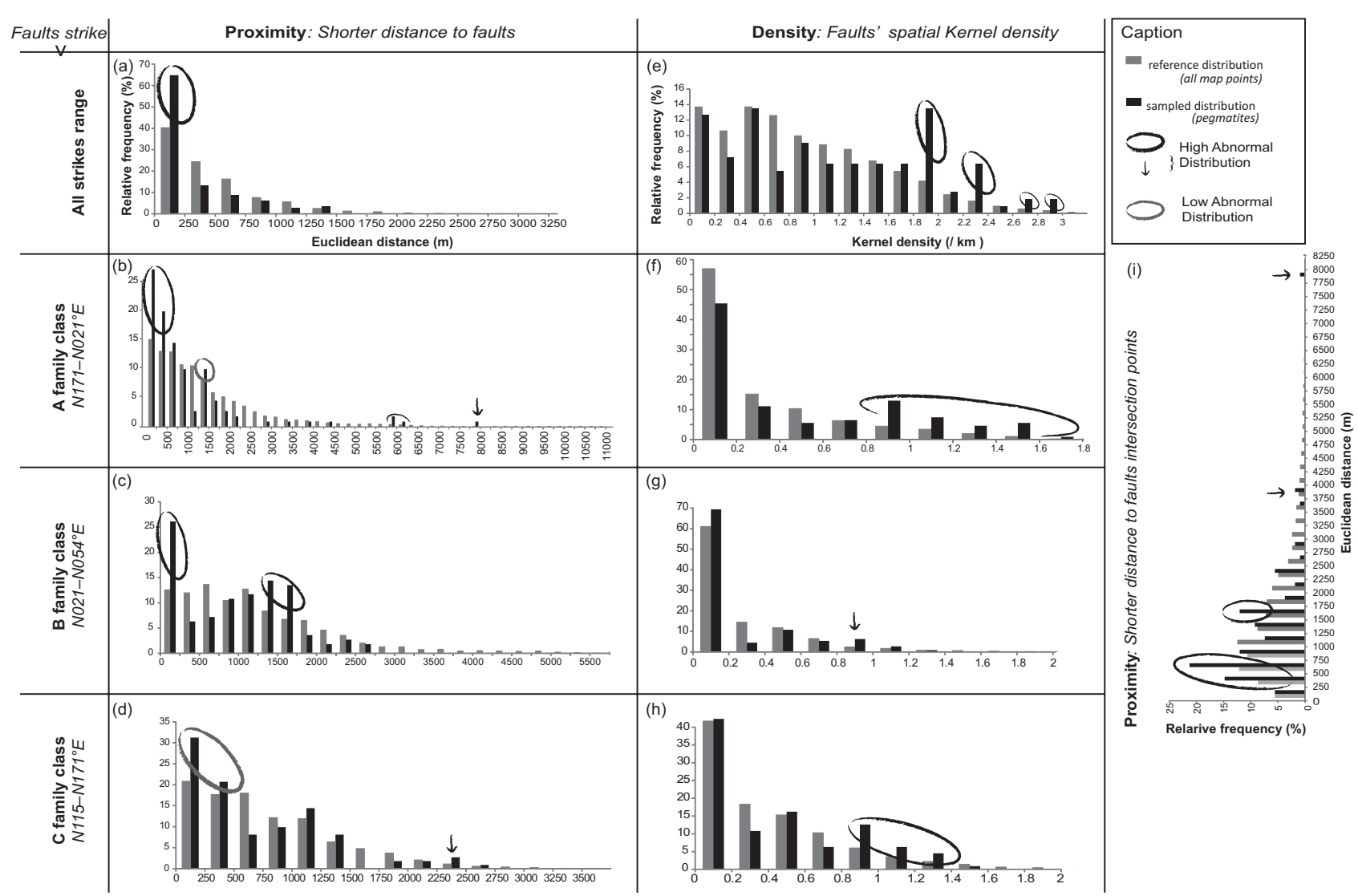

Fig. 6 Results of the geostatistical tests; proximity and density calculation analyzed with pegmatite, faults and fault intersection points.

\subsection{Proximity analysis between pegmatites and fault-strike families}

\subsubsection{All faults}

Analysis of the shortest distance between pegmatites and faults (Fig. 6a) shows that the pegmatites frequency distribution extends from 0 to $1500 \mathrm{~m}$ (black bars in Fig. 6a), whereas the reference distribution extends from 0 to 3500 $\mathrm{m}$ (grey bars in Fig. 6a). The first [0-250 $\mathrm{m}$ [ distance class shows that the pegmatites frequency displays a higher value $(65 \%)$ than the reference one $(40 \%)$. The sampled pegmatites distribution to reference distribution ratio is thus $65 / 40=1.6$. Thereby, the pegmatites distribution is a HAD up to $250 \mathrm{~m}$. In contrast, beyond 250 $\mathrm{m}$, the pegmatites frequency is lower than the reference value, and the pegmatites distribution can be considered as a ND. This result highlights that pegmatites are statistically grouped along faults and, as a whole, these may have an apparent control on pegmatites emplacement at a [0-250 $\mathrm{m}$ [distance. Consequently, to quantify and further constrain the relative control of faults on pegmatites emplacement, the same frequency analysis of the shortest distance between pegmatites and faults is undertaken with each fault-trend family (A, B, C).

\subsubsection{A-family faults}

The pegmatites distribution extends from 0 to $8000 \mathrm{~m}$, and from 0 to $11000 \mathrm{~m}$ for the reference distribution (Fig. 6b). The [0-500 $\mathrm{m}$ [distance class shows that the pegmatites frequency displays a higher value (46\%) than the reference frequency $(27 \%)$, in the same distance class considered. The sampled pegmatites distribution to reference distribution ratios equal to 1.96 and 1.54 for the [0-250 m [and [250-500 m [distance classes, respectively. Therefore, the pegmatites distribution can be regarded as a HAD to be replaced, beyond $500 \mathrm{~m}$, by a ND type. Such feature highlights that A-faults have a strong apparent control on pegmatites distribution up to $500 \mathrm{~m}$. Note that a HAD is observed in distance classes; [4250-4500 $\mathrm{m}$ [ , [5750-6000 m [ , [6000-6250 m [ with pegmatites distribution to reference distribution ratios of 1.8, 6.9 and 3.8 respectively. However, the frequency values are very low (1 to $2 \%$ ) and the ratios are of little significance.

\subsubsection{B-family faults}

The pegmatites distribution extends from 0 to $2750 \mathrm{~m}$ and from 0 to $5750 \mathrm{~m}$ from the reference distribution (Fig. 6c). The [0-250 $\mathrm{m}$ [distance class shows that the 
pegmatites frequency value $(26 \%)$ is higher than the reference one $(12.6 \%)$. The pegmatites distribution to the reference distribution ratio is very high (2.07), and thus, the pegmatites distribution can be considered as a HAD. Again, this highlights that B-faults have an apparent control on the pegmatites location in the [0-250 $\mathrm{m}$ [distance class. Then, in the [250-1250 $\mathrm{m}$ [distance range pegmatites follow a ND. These results confirm that B-faults have an apparent control on the pegmatites location only in the [0-250 m [distance class. Note that two distance classes, [1250-1500 m [and [1500-1750 m [ show that pegmatites follow a HAD with ratios of 1.7 and 1.9 respectively; such feature will be discussed later.

\subsubsection{C-family faults}

Finally, the pegmatites distribution extends from 0 to $2750 \mathrm{~m}$ whereas the reference distribution is broader, from 0 to $3750 \mathrm{~m}$ (Fig. 6d). The [0-250 m [distance class shows that the pegmatites frequency value $(31.6 \%)$ is higher than the reference frequency $(21 \%)$. The ratio of these two distributions is of 1.5 and so the pegmatites distribution can be regarded as a HAD. This highlights at the shortest distance that $\mathrm{C}$-faults have an apparent control on the pegmatites' location. Beyond $250 \mathrm{~m}$, pegmatites follow a LAD in the [1000-1250 $\mathrm{m}$ [and [1250-1500 m [distance classes with ratios of 1.2 and 1.27 respectively. At larger distance from C-faults, in the [2250-2750 m [distance range, pegmatites display an HAD, with distributions' ratios of 2.4 and 1.57 respectively. Again, the corresponding frequency values are not more than $2 \%$ and the ratios are thus of little significance.

As a whole, the pegmatites distribution is spatially controlled by the A-family faults oriented in the $\mathrm{N} 171^{\circ} \mathrm{E}-$ $\mathrm{N} 021^{\circ} \mathrm{E}$ trend class. Indeed, $53 \%$ of pegmatites set are spaced less than $500 \mathrm{~m}$ from an A-fault. Nevertheless, some pegmatite occurrences are spatially related to $\mathrm{B}-$ and $\mathrm{C}$-faults when the distance increases between [1000-1750 $\mathrm{m}$ [distance range and beyond $2000 \mathrm{~m}$.

\subsection{Spatial relationships between pegmatites and spatial density of faults}

In this second part, we focus on the frequency analysis of the measured spatial density of faults with regard to the densities at pegmatites location. The same descriptive approach is followed to highlight anomalous distributions (Fig. 6).

\subsubsection{All fault families}

The pegmatites sampled distribution density is $0-2.8$ (number of faults per $\mathrm{km}^{2}$ ), and from 0 to 3.2 for the reference distribution (Fig. 6e). Note that no pegmatite is locat- ed in an area totally devoid of faults. In the [0-1.8[density range, the pegmatites frequency values are all similar or lower than the reference frequency values. However, in the [1.8-2[density class, the pegmatites frequency is much higher than the reference value in the same density class. The ratio of the two distributions is 3.9. Thereby the pegmatites distribution can be regarded as a HAD. The same pattern is observed in three other density classes, [2.2-2.4[, [2.6-2.8[and [2.8-3[with distributions' ratios of 3.9, 3.1 and 5.08 respectively. This result highlights that the density of faults has an apparent control on the pegmatite location.

Again, in order to quantify and constrain the relative control of faults' density for different direction families (see above) on pegmatites emplacement, the same frequency analysis of the faults density estimation at pegmatites location is carried out with each fault-trend family.

\subsubsection{A-family faults}

The distribution of the sampled pegmatites distribution and the reference one both extend from 0 to 1.8 (Fig. 6f). In the $[0-0.8$ [density range, the pegmatites frequencies are all similar to, or lower than, the reference values and the sampled pegmatites distribution can thus be regarded as a ND. However, beyond 0.8 density, all pegmatites frequencies are higher than the reference values. The pegmatites distribution to reference distribution ratio ranges from 2.1 in the [1-1.2 [density class to 5.26 in the [1.4-1.6[interval. Thus, pegmatites follow a clear HAD. This highlights that the A-faults' density has an apparent control on the pegmatites location.

\subsubsection{B-family faults}

The pegmatites distribution is narrower $(0-1.4)$ than the reference distribution with a maximum density of 2.2 (Fig. 6g). At the lowest densities [0-0.8[, the pegmatites frequencies are similar to, or lower than, the reference value (90\% vs. $93 \%$ ). However, in the [0.8-1[and [1-1.2[ density classes, the distribution ratios are 2.59 and 1.55 respectively. Thereby the pegmatites distribution can be regarded as a HAD and this confirms that the B-faults density has an apparent control on the pegmatite locations.

However, note that only $10 \%$ of pegmatites are spatially related to the highest B fault density. So, the B-faults density is not a major factor, in contrast to the A-faults one (i.e. $53 \%$ of pegmatites spatially related to the highest A-faults densities).

\subsubsection{C-family faults}

The pegmatites frequency distribution is narrower $(0-1.6)$ than the reference one, with a maximum den- 
sity of 2.2 (Fig. $6 \mathrm{~h}$ ). In the [0-0.8 [density range, the pegmatite frequencies are similar to, or lower than, the reference values. Thus the pegmatites follow a ND characterized by distribution ratios of $0.6-1.05$. However, in the [0.8-1.4[density class, pegmatites frequency values $(24 \%)$ are higher than the reference ones (11.5 $\%$ ). The pegmatites distribution to reference distribution ratios are all higher than 1.5 , for a maximum of 2.05 in the $[1.2-1.4$ [density class. This demonstrates that the pegmatites follow a HAD and that the C-faults density has an apparent control on the pegmatites locations. Some $23 \%$ of pegmatites are located in domains of high C-faults density, which represent a lower surface than domains of low C-faults density containing $75 \%$ of the pegmatites.

In conclusion, the location of the pegmatite bodies seems mainly controlled by zones of high A-faults density. However, $10 \%$ and $23 \%$ of them are spatially associated with the highest $\mathrm{B}$ and $\mathrm{C}$-faults densities, respectively (Fig. 6g-h). These results are consistent with the previous spatial proximity analysis between the pegmatites and A-, B- and C- fault families. It is also reasonable to assume that zones of intersections of several faults of these types are more favorable to host pegmatites than the regions with only isolated structures.

\subsection{Spatial relationships between pegmatites and fault-intersection points}

Here the association of the shortest measured distance between faults intersections and pegmatite occurrence is tested (Fig. 6i). Such a statistical test allows focusing on the role of the highly fractured zones where different fault sets - which possibly developed at different periods - intersect.

The sampled pegmatites and reference distributions extend from 0 to $8000 \mathrm{~m}$ and 0 to $8250 \mathrm{~m}$, respectively. The [250-750 $\mathrm{m}$ [distance range shows that the pegmatites frequency values are higher $(36 \%)$ than the reference ones $(20 \%)$. The distributions' ratios are 1.7 and 1.75 for the [250-500 $\mathrm{m}$ [and [500-750 $\mathrm{m}$ [density classes, respectively. Thus the pegmatites follow a HAD. Similar distributions are observed at larger distances ([1500-1750 $\mathrm{m}$ [and [3750-4000 $\mathrm{m}$ [distance classes) between pegmatites and faults intersections but too far to be interpreted as a causal link. However, the HAD observed closer can be regarded as an apparent control of faults intersections on the pegmatites emplacement. Following the first-order results detailed above, we suggest that the pegmatites emplacement is "potentially" (i.e. any pegmatite occurrences recognized on the $[0-250 \mathrm{~m}$ [distance class) controlled by A and C-faults' intersection points.

\subsection{Spatial relationships between pegmatite types and $\gamma 2-\gamma 3$ granitic facies}

In order to get information on the spatial association between pegmatites and some particular lithologies, the shorter distance of points (pegmatites) from certain polygons (selected lithologies) is studied. In this section, we focus on the frequency analysis of the shortest distance measured between $\gamma 2$ and $\gamma 3$ granitic units and occurrences each of the pegmatite types (Fig. 7).

\subsubsection{Distance from the $\gamma 2$ (Fanay granite)}

K-type pegmatites distribution extends from 0 to 20,250 $\mathrm{m}$ whereas the reference distribution is more extensive, from 0 to $27,000 \mathrm{~m}$ (Fig. 7a). From the $[250-500 \mathrm{~m}$ [2750 $\mathrm{m}$ [distance class, pegmatite frequency values are all higher than the reference ones. The two distributions ratios are all $\geq 1.5$. So, $60 \%$ of $\mathrm{K}$-type pegmatites follow a HAD in the [250-2750 m [distance range. However, note that only $1 \%$ of pegmatites are located at a distance less than $250 \mathrm{~m}$ from the $\gamma 2$ granitic unit. So, this shows that the $\gamma 2$ granitic unit has an apparent control on the $\mathrm{K}$-type pegmatites locations, but no pegmatite is located inside the $\gamma 2$ intrusion.

SK-type pegmatites distribution extends up to $2500 \mathrm{~m}$, whereas the reference distribution reaches up to 27,000 m (Fig. 7b). SK-type pegmatites clearly follow a HAD. This distribution is characterized by $75 \%$ of SK-type pegmatites located in the [500-1250 $\mathrm{m}$ [distance range. This highlights that the $\gamma 2$ granitic unit has an apparent control on the SK-type pegmatites locations and that these are closer ( $75 \%$ of pegmatites in the [500-1250 m [distance class) to $\gamma 2$ Fanay granite than K-type pegmatites are (31\% of pegmatites in the same distance range).

SK-L type pegmatites distribution extends up to 3750 $\mathrm{m}$, and the reference distribution up to $27,000 \mathrm{~m}$ (Fig. 7c). All pegmatites frequencies exceed the reference values and show that pegmatites follow a HAD. Note that much of the pegmatites ( $40 \%)$ is located in the [500-750 $\mathrm{m}$ [distance class. Thus, $50 \%$ of SK-L type pegmatites are located closer than $750 \mathrm{~m}$ from the $\gamma 2$ Fanay granite. This frequency value rises to $70 \%$ in the $[500-1250 \mathrm{~m}$ [distance class. Note that this frequency value is similar to the SK pegmatites one $(75 \%)$ in the same distance range.

SL-type pegmatites are all located within [4000-4250 $\mathrm{m}$ [ (Fig. 7d). Here again, the pegmatites distribution is highly abnormal (HAD) and this suggests that the $\gamma 2 \mathrm{Fa}-$ nay granite apparent by controls the SL-type pegmatites locations.

In conclusion, the distributions of SK, SK-L and SLtype pegmatites are limited to a distance ranges from 0 to $4.25 \mathrm{~km}$. The K-type pegmatites are the only ones to 


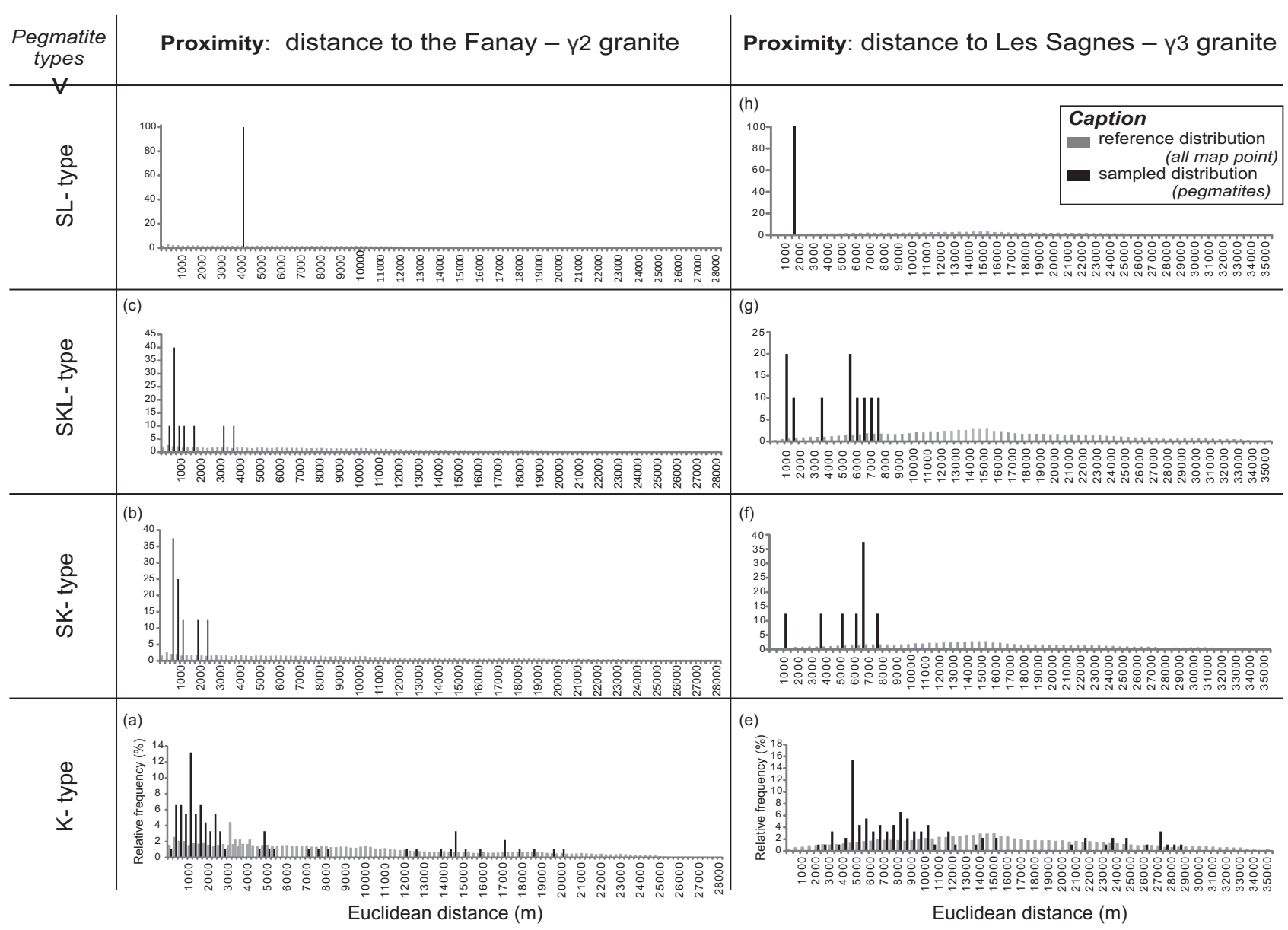

Fig. 7 Results of the spatial proximity analysis calculated from each type of pegmatites and $\gamma 2, \gamma 3$ granitic facies.

be located further than $4.25 \mathrm{~km}$ (up to $20 \mathrm{~km}$ ) from the $\gamma 2$ granite. Thereby all pegmatites types overlap in the same distance range from $\gamma 2$ granite; distances between $\gamma 2$ granite and the least differentiated pegmatites and, those more fractionated may be similar. The more fractionated pegmatite types (i.e. SK-L and SL) are not the most remote ones from the $\gamma 2$ granite.

\subsubsection{Distance from the $\gamma 3$ (Les Sagnes granite) unit}

K-type pegmatites distribution is very broad, $2-29 \mathrm{~km}$ and $0-35.7 \mathrm{~km}$ for the reference distribution (Fig. 7e). In contrast to Fig. 7a, any K-type pegmatite is located less than $1 \mathrm{~km}$ from the $\gamma 3$ Les Sagnes granite. The highest pegmatite frequency $(14.5 \%)$ is observed in the [4500-5000 m [distance class.

SK-type pegmatites distribution ranges from 1 to 8 $\mathrm{km}$ and from 0 to $35 \mathrm{~km}$ for the reference distribution (Fig. 7f). As we can observe in Fig. 7e, no pegmatite is located at a distance less than $1 \mathrm{~km}$ from $\gamma 3$ Les Sagnes granite. Moreover, the highest pegmatite frequency $(37 \%)$ is observed in the [6500-7000 $\mathrm{m}$ [distance class.
SK- $L$ type pegmatites distribution is the same as the SK-type pegmatites distribution (Fig. $7 \mathrm{~g}$ ) and extending from 1 to $8 \mathrm{~km}$. The pegmatites are the most frequent $(20 \%)$ in two distance classes, [1-1.5 km [and [5.5-6km [.

SL-type pegmatite, are located exclusively at a distance 1.5-2 km from the $\gamma 3$ Les Sagnes granite (Fig. 7h). Thereby, the SL-type pegmatites are the spatially closest to the $\gamma 3$ granite whereas the $\mathrm{K}$-type pegmatites are the furthest.

Following the model of London (2008), the youngest $\gamma 3$ intrusion cannot be parental to the K, SK and SK-L pegmatite types. SL-type pegmatites could be potentially derived from $\gamma 3$ intrusion but nothing explains the lack of intermediate pegmatite types and the first occurrence of SL-type pegmatites at $1.5-2 \mathrm{~km}$ from granitic intrusion.

\section{Cluster mapping}

Following the pegmatites spatial distribution analysis given above, clusters mapping has been performed from the pegmatite points set in order to i) highlight the zones 
of particular grouping of the occurrences and ii) quantify any preferential alignment direction of the points, with the corresponding "anisotropy" value (Fig. 8). Such mapping could thus help pointing out the spatial associations and potential common trends with the structures. This method has been applied for automated analysis of spatial distribution of seismic events and details on the algorithm were also given in Allanic and Gumiaux (2013). In brief, computation of a hierarchical classification of the DNN was made from the pegmatites point set. Then separation of the set into groups (Fig. 8b) was based on the determination of the maximum reference distance (MRD) (i.e. clustering distance); i.e. two pegmatite points separated by this MRD belong to the same group. Lastly, a standard deviational ellipse centered on the barycenter of each cluster is computed. The angle of strike of its long axis gives the direction of the points' alignment (Fig. 9a).

In the case of the Monts d'Ambazac pegmatites field, two MRD values, 2000 and 5000, have been tested following the preliminary analysis of the pegmatites distribution (in Section 3). All the statistics coming from this cluster analysis are compiled in Tab. 1. First, a MRD value of $5000 \mathrm{~m}$ was used for all pegmatite types. Three clusters were computed with one cluster (group ID =1) representing 101 pegmatite points over 118. This cluster is characterized by an average DNN of $413 \mathrm{~m}$. Its trend is $17.4^{\circ}$, which belongs to the Afault trend class. The MRD value of $2000 \mathrm{~m}$ was used for each pegmatite type. The K-type pegmatites are grouped into 7 clusters. Four clusters (i.e. Group ID = 1, 2, 4 and 5) present the same average trend as A- and $\mathrm{C}$-fault trend classes. Clusters characterized by group ID 1 and 2 are the most representative of the K-type pegmatite distribution with 33 and 23 pegmatite points, respectively. These two clusters are oriented $\sim \mathrm{N} 015^{\circ}$ and $\sim \mathrm{N} 017^{\circ}$. The SK-type pegmatite distribution is defined by an average DNN of $374 \mathrm{~m}$ and by only one cluster oriented $\mathrm{N} 36^{\circ}$. This cluster belongs to the Bfault trend class. The SK-L type pegmatite distribution is defined by an average DNN of $374 \mathrm{~m}$ as well, and by only one cluster oriented in the same direction as A-fault trend class $\left(\mathrm{N} 171^{\circ}\right)$. Consequently, we infer that the clusters trend of $\mathrm{K}$ and SK-L pegmatite sets is parallel to the A-fault trend class. This result is also observed on large scale (clustering distance $=5000 \mathrm{~m}$ ) with all considered pegmatite types. Finally, SL-type pegmatites are gathered in the same cluster oriented $\mathrm{N} 065^{\circ}$. This trend does not correspond to any of the recognized fault families. Thus we suggest that the genesis and emplacement mode of the SL-type pegmatites are different from those of less differentiated K- (A-fault trend class), SK- (B-fault trend class) and SK-L (A-fault trend class) types.

\section{Summary and interpretations}

Four groups of pegmatites defined as K (beryl-columbite subtype), SK (beryl-columbite to beryl-columbite-phosphates subtypes), SK-L (beryl-columbite-phosphates subtype) and SL (lepidolite subtype) types were emplaced within the SSGC. Only some pegmatites of SL type are located in country rocks of the SSGC off its southern edge. In a map view, pegmatites that compose the whole field appear as clustered, which is a very common feature of most pegmatite fields worldwide. Such feature is demonstrated throughout the present statistical study; Distance to Nearest Neighbor analysis (average DNN $=528 \mathrm{~m}$ and $\mathrm{R}$ ratio $=0.36$ ) and Ripley's L'-function computations disclose a prominent clustering distribution of pegmatites for a MRD up to $5000 \mathrm{~m}$. A particularly high clustering rate is identified from 0 to $2000 \mathrm{~m}$. Ten pegmatite clusters are defined for a MRD fixed at 2000 $\mathrm{m}$ (Tab. 1). Altogether, these results demonstrate that pegmatites are highly clustered and that clustering occurs on all scales up to $5000 \mathrm{~m}$.

We also analyzed the shape and spatial trend of the clusters with respect to the fault trends (Tab. 1). Four clusters representing $56.7 \%$ of all pegmatites display a similar trend as A-fault family $\left(\mathrm{N} 015^{\circ} \mathrm{E}\right)$, whereas four clusters (representing only $13.6 \%$ of all pegmatites) present a similar trend as B- and C-fault families. Some $21.1 \%$ of pegmatites are isolated points or belong to clusters with ellipse shape ratio less than, or equal to, unity. The remaining $8.5 \%$ are grouped in a single SLtype pegmatite cluster. For a MRD fixed at $5000 \mathrm{~m}$, only three pegmatite clusters are computed. Among them, the group ID 1 (Tab.1), which includes most points (101, i.e. $85.6 \%$ of all pegmatites), is parallel $\left(\mathrm{N} 017^{\circ} \mathrm{E}\right)$ to the Afault family. This shows that, on all scales, the pegmatites set distribution is clustered and mainly oriented in the A-faults trend.

The spatial statistical analysis shows that $46 \%$ of the pegmatites occur at less than $500 \mathrm{~m}$ from an Atype fault (i.e. [N $171^{\circ} \mathrm{E}-\mathrm{N} 021^{\circ} \mathrm{E}$ [range; Fig. 6b). This result is confirmed by the spatial correlation between the pegmatites occurrences $(35 \%)$ and the highest fault densities (Fig. 6f). Moreover, this faults-rich zone

Fig. 8a - Clusters' spatial extent and trend computed in the whole SSGC for each of the pegmatite types (K, SK, SK-L and SL). Number in parentheses corresponds to the pegmatite points included in each standard deviational ellipse. Arrows are centered on the barycenter of each ellipse and give the direction of the pegmatite points' alignment (Allanic and Gumiaux, 2013). b - Pegmatite points' clusters distribution computed in the Monts d'Ambazac pegmatite field for all the pegmatite types. Numbers in parentheses correspond to the pegmatite points included in each group ID according to the clustering distances of 2000 $\mathrm{m}$. The size of each arrow is proportional to the number of pegmatite points. See text for details. 


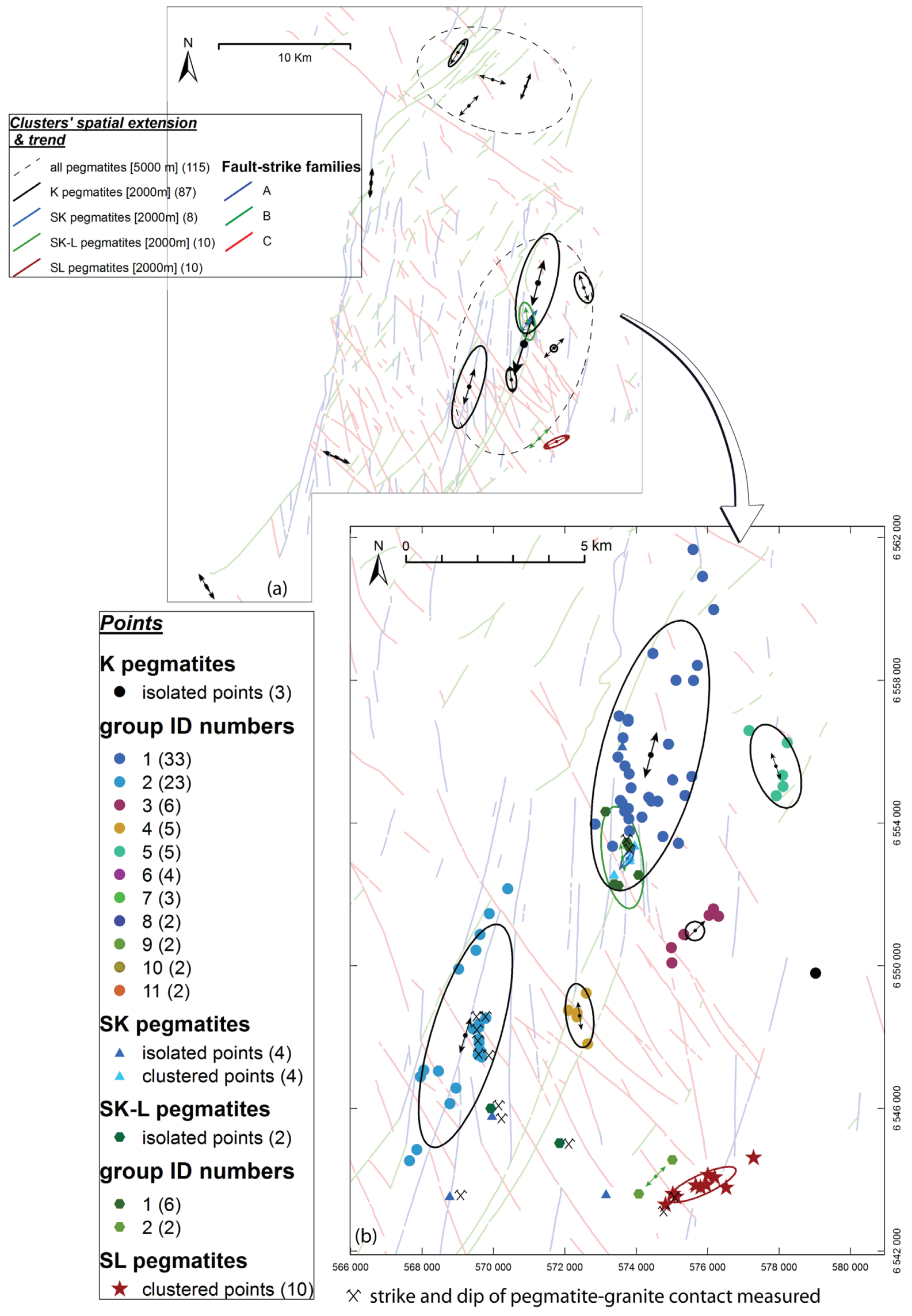




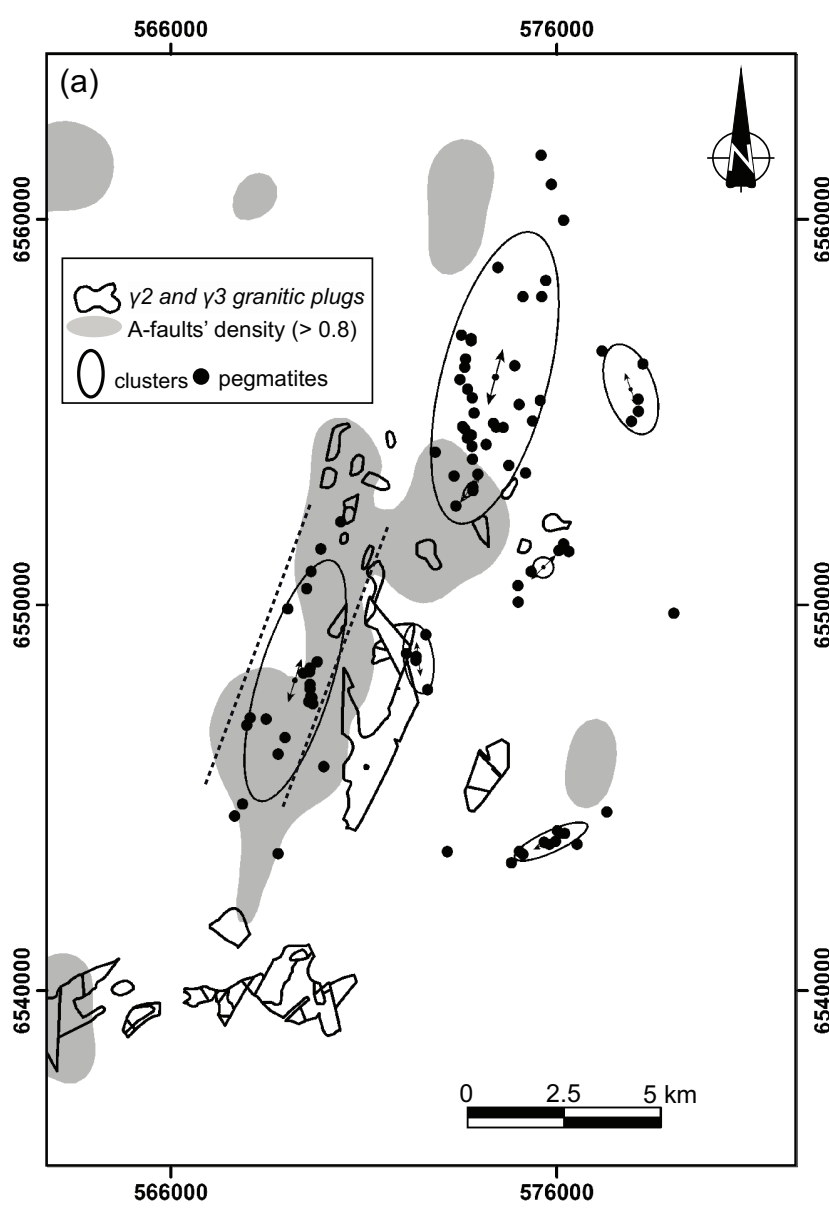

(b)

Schematic model showing High Anomalous Distribution of pegmatites in the vicinty of A-type faults and the high density of B- or C-type faults

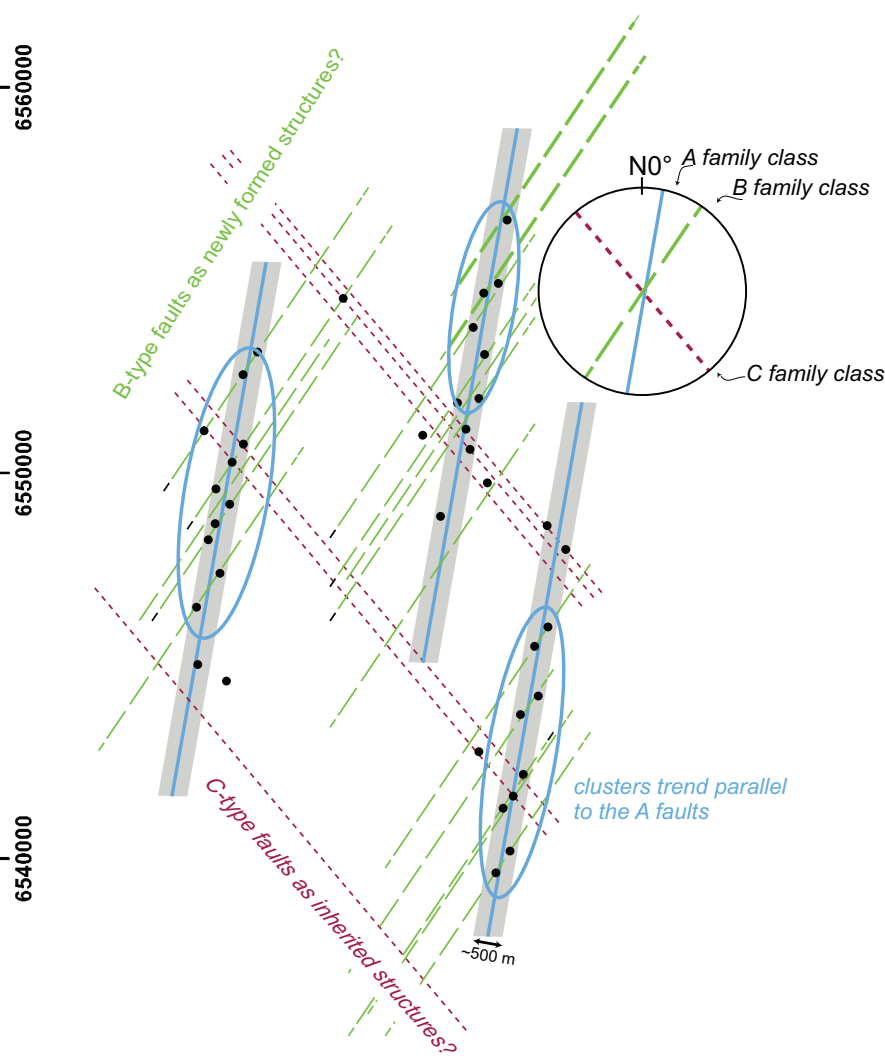

Fig. 9a - High density of the A-type faults is parallel to the large sheared-band located in the central part of the SSGC with pegmatites and clusters trends automatically mapped in this area (see Fig. 8). b-Schematic model illustrating the High Abnormal Distributions of pegmatites in the vicinity of A-type faults and the high density zones of B- or C-type faults.

forms a band superimposed in the sheared corridor in the central part of the SSGC (Fig. 9a). The average $\mathrm{N} 007^{\circ}$ A-fault direction is almost parallel with this corridor (Fig. 1a-b). To conclude, results from this study imply: i) a preferred spatial association between pegmatites and A-family faults; ii) a correlation of pegmatites with the highest A-family faults density and iii) a parallelism between A-faults and pegmatite clusters trends. Thus, a clear spatial relationship between pegmatites and A-family faults is confirmed. Orientations of the pegmatites are consistent with these results (Fig. 2).

Weak links between C- and B-family faults and pegmatites are observed in the ranges $1250-1500 \mathrm{~m}$ and 1500-1750 m, respectively. However, the control of B- and C-faults on the location of the pegmatites has been previously defined as minor (26\% and $31.6 \%$ associated, respectively) compared to A-faults. Thus, we suggest that the emplacement of pegmatites along $\mathrm{B}$ - and C-faults trend is possible but the most favorable configuration to localize pegmatites is the combination of the two parameters: high density of B- or C-faults and the proximity to A-type faults. However, this does not mean that pegmatites and these faults were coeval, but pegmatites have probably used brittle faults as pathways. The lack of structural parameters does not allow us to be more precise.

The frequency analysis of the shortest distance between each of the pegmatite types and $\gamma 2-\gamma 3$ granitic boundaries highlights that: i) statistical distributions of the individual types (K, SK, SK-L and SL) overlap, and ii) maximum frequency values stand for rather large distances $(\sim 1 \mathrm{~km})$. Therefore one cannot conclude that spatial relationship exists between given pegmatite type and $\gamma 2-\gamma 3$ granites.

Besides, several elements underline that SL pegmatites differ from the others. Indeed, this pegmatite type is very different from the other ones. Following field observations, all pegmatite occurrences of the Chèdeville district (Fig. 1b) display a sharp contact with the host-rocks (i.e. $\gamma 1$ granite and metamorphic rocks). It should be noted that the $\mathrm{N} 065^{\circ}$ trending cluster located on the southern SSGC contact is isolated and its direction does not correspond to any of the three faults strike families recognized. The Chèdeville district yields an age of $309 \pm 1$ 
Tab. 1 Review of different calculations performed to realize the clusters automatic mapping of all pegmatites and each pegmatite types with clustering distances of 5000 and $2000 \mathrm{~m}$, respectively

\begin{tabular}{|c|c|c|c|c|}
\hline group ID* & $\begin{array}{c}\text { no. of points } \\
\text { per cluster }\end{array}$ & trend $\left(^{\circ}\right)$ & trend class** & $\begin{array}{c}\text { ellipse shape } \\
\text { ratio*** }\end{array}$ \\
\hline \multicolumn{5}{|c|}{ all pegmatites [5000 $\mathrm{m}$ clustering dist.] } \\
\hline 1 & 101 & 17.4 & A & 1.7 \\
\hline 2 & 10 & 107.7 & $d$ & 1.6 \\
\hline 3 & 3 & 148.2 & $\mathrm{C}$ & 24.0 \\
\hline 4 & 2 & 114.4 & - & - \\
\hline 5 & 2 & 4.5 & - & - \\
\hline \multicolumn{5}{|c|}{ type K pegmatites [2000 m clustering dist.] } \\
\hline 1 & 33 & 14.6 & A & 2.8 \\
\hline 2 & 23 & 16.9 & A & 3.4 \\
\hline 3 & 6 & 45.4 & - & 1.0 \\
\hline 4 & 5 & 172.7 & A & 2.3 \\
\hline 5 & 5 & 160.5 & $\mathrm{C}$ & 2.0 \\
\hline 6 & 4 & 33.4 & $\mathrm{~B}$ & 3.7 \\
\hline 7 & 3 & 148.2 & $\mathrm{C}$ & 24.0 \\
\hline 8 & 2 & 114.4 & - & - \\
\hline 9 & 2 & 4.5 & - & - \\
\hline 10 & 2 & 43.3 & - & - \\
\hline 11 & 2 & 21.0 & - & - \\
\hline \multicolumn{5}{|c|}{ type SK pegmatites [2000 m clustering dist.] } \\
\hline- & 4 & 36.2 & $\mathrm{~B}$ & 2.1 \\
\hline \multicolumn{5}{|c|}{ type SK-L pegmatites [2000 m clustering dist.] } \\
\hline 1 & 6 & 171.0 & A & 2.6 \\
\hline 2 & 2 & 44.5 & - & - \\
\hline \multicolumn{5}{|c|}{ type SL pegmatites [2000 m clustering dist.] } \\
\hline- & 10 & 65.4 & $d$ & 3.7 \\
\hline
\end{tabular}

Each cluster is defined by a group ID, the number of points, average distance nearest neighbor $(\mathrm{DNN})$, trend $\left({ }^{\circ}\right)$; trend fault class $(\mathrm{A}, \mathrm{B}, \mathrm{C}$ or $d$ ) related it and its ellipse shape ratio. Each group ID is illustrated in Fig. 8b.

* isolated points of each pegmatite type are not considered in this table ** trend classification is based on the one of faults populations (see Fig. 7; it is determined for clusters $>2$ points and for cluster ellipse shape ratio $>1.0$ )

*** ellipse shape ratio value is by definition infinite for " 2 points clusters"

Ma (Ar-Ar method on lepidolite, Cheilletz et al. 1992) whereas the SSGC emplacement has been dated at 324 $\pm 4 \mathrm{Ma}$ (U-Pb method on zircon and monazite, Holliger et al. 1986). Consequently, all evidence suggests that i) the SL pegmatites probably have not been extracted from the same source as the other types and ii) SL pegmatites clustering seems to be controlled by a specific mechanism. Obviously, some geochemical data are required, in addition to the geochronological information, to confirm our model, such as: i) a detailed isotopic study (e.g. Sr,
$\mathrm{Nd}, \mathrm{Pb}, \mathrm{Li}$ and $\mathrm{O}$ ); ii) a mineral chemistry for each of the pegmatite types to compare with geochemical data from granites and finally iii) a precise $\mathrm{U}-\mathrm{Pb}$ geochronological study of Fanay and Les Sagnes granites.

\section{Discussion}

Clustering pattern of the pegmatite fields has often been described but the underlying mechanisms remain only poorly constrained up to date. Two models can be considered (or a possible combination of the two): i) a "source" model whereby pegmatite clusters are formed within and/ or in the vicinity of intrusive granite plugs, which display limited spatial extent and which would be the source of the pegmatite clusters; ii) a "trap" model with dispersion of the pegmatites being controlled by the one of the structures in the upper crust (connected to a magmatic source at depth). Indeed, studies on brittle deformation and rock behavior show that faults typically develop in clusters and can follow a fractal type spatial organization, i.e. with clustering occurring on different scales (e.g. Sornette et al. 1990; Steacy and Sammis 1991; Velde et al. 1991; Cowie et al. 1995). As shown in this study, spatial statistical analysis provides powerful tools for evaluating the respective role of such two mechanisms.

The $\gamma 2-\gamma 3$ granites are often considered as potential magmatic source (see above). Following the theoretical fractionation model of pegmatite development (London 2008), the differentiation degree increases with increasing distance away from the parental granites. Statistical analysis of the computed distances between pegmatites and country rocks should thus display contrasting frequency distributions when considering different types of pegmatites, i.e. increasing the average distance in the $\mathrm{K}$, SK, SK-L, SL sequence. In contrast, our study highlights similar frequency distributions. This is also visible on the map where several $\gamma 2-\gamma 3$ granitic plugs do not display any occurrence of pegmatite in their vicinity (Fig. 9a). No spatial link between pegmatites and granites can be deduced in the Monts d'Ambazac case study.

Conversely, the present statistical study clearly proves that the structural control mechanisms are dominant, fault traces being the key parameter controlling the distribution of the pegmatite clusters.

Due to the lack of structural data, no precise relative timing can be established among the three faults strike families. Nevertheless, based on the fault-strike analysis (see Fig. 9b), a mechanical model could be proposed. In a brittle regime, A-type faults developed after and parallel to the medial sheared corridor - which has been interpreted as a "right lateral magmatic shear zone" (Fig. 9a; e.g. Mollier and Bouchez 1982; Mollier and Lespinasse 1985; Cuney et al. 1990; Hottin et al. 1995). Strike of 
the B-type faults is also compatible with such a deformation regime and faults can be considered either as newly formed structures or as reactivated ones (e.g. extensional jogs). Regarding their orientation, C-type faults are most likely inherited structures. In this theoretical setting, pegmatites were preferentially emplaced at the intersections between the newly-formed A-type strike-slip faults and the zones with high density of the B- or C-type faults (see corresponding locations in Fig. 9b). Nonetheless, further field and microstructural studies are needed to test this working hypothesis.

To conclude, this method is really suitable to study spatial relationships between pegmatites and their environment and to constrain the pegmatite emplacement mechanism. Such a study is clearly less time consuming than any analytical one. However, analytical studies such as geochemical and/or isotopic analyses are best suited to establish the genetic links between pegmatites and granites. Our statistical approach could be employed in other pegmatite fields where outcrop conditions are favorable to observe and validate statistical results by further structural measurements.

Acknowledgments. We thank Manuel Demartis and David London for their constructive and interesting remarks, Editor-in chief Vojtech Janousek and Associate Editor Pavel Uher for their constructive comments that considerably improved the quality of the manuscript, Michel Cuney for his participation on the last field campaign and for sharing his knowledge during our discussions of the study area, Laurent Guillou-Frottier for manuscript handling and Nicolas Charles and Arnaud Villaros for their comments. This research was co-funded by the French Geological Survey (BRGM), Région Centre and The Labex VOLTAIRE.

\section{References}

Allanic C, Gumiaux C (2013) Are there any active faults within Lepontine Dome (Central Alps)? Bull Soc Géol France 184, 4: 433-445

Arène J, Autran D, Cofrant H, Labernardière L, Burnol L (1972) Geological map of France, 1:50,0000, sheet Bourganeuf (665). BRGM, Orléans

Aubert G (1969) Granitic cupolas of Montebras and Echassières (French Massif Central) and the genesis of tin, lithium, tungsten and beryllium mineralizations. Mém Bur Rech Géol Min 46: 1-345 (in French)

Audrain J, Vigneresse J, Cuney M, Friedrich M (1989) Gravimetric model and the emplacement of Saint Sylvestre peraluminous granitic complex (French Massif Central). C R Acad Sci Paris 309: 1907-1914 (in French)

Baloga SM, Glaze LS, Bruno BC (2007) Nearestneighbor analysis of small features on Mars: application to tumuli and rootless cones. J Geophys Res, Planets 112: E03002

BERMAn M (1977) Distance distributions associated with Poisson processes of geometric figures. J Appl Probab14: 195-199

Berman M (1986) Testing for spatial association between a point processes and another stochastic process. Appl Stat 35: 54-62

Bleacher Je, Glaze LS, Greeley R, Hauber E, Baloga SM, Sakimoto SEH, Williams DA, Glotch TD (2009) Spatial and alignment analyses for a field of small volcanic vents south of Pavonis Mons and implications for the Tharsis Province, Mars. J Volcanol Geotherm Res 185: 96-102

BONHAM-CARTER GF (1985) Statistical association of gold occurrences with Landsat-derived lineaments, TimminsKirkland Lake area, Ontario. Canad. J Remote Sensing 11: 195-211

BONHAM-CARTER GF (2002) Geographic information system from geoscientists: modeling with GIS. Pergamon, Oxford, pp 1-398

BURNOL L (1974) Beryllium geochemistry and concentration types in French Massif Central leucogranites. Relationships between geochemical features of granites and endogenous deposits $(\mathrm{Be}, \mathrm{Sn}, \mathrm{Li})$ or of late reworking deposits (U, F, Pb and Zn) Mém Bur Rech Géol Min 85: 1-168 (in French)

Carranza EJM, Hale M (2002) Mineral imaging with Landsat TM data for hydrothermal alteration mapping in heavily-vegetated terrane. Int J Remote Sensing 23: $4827-4852$

CARRANZA EJM (2009a) Controls on mineral deposit occurrence inferred from analysis of their spatial pattern and spatial association with geological features. Ore Geol Rev 35: 383-400

CARRANZA EJM (2009b) Geochemical anomaly and mineral prospectivity mapping in GIS. Handbook of Exploration and Environmental Geochemistry, vol. 11, Elsevier, Amsterdam, pp 1-368

Cassard D, Billa M, Lambert A, Picot JC, Husson Y, Lassere JL, Delor C (2008) Gold prospectivity mapping in French Guiana using an expert-guided data-driven approach based on a regional-scale GIS. Ore Geol Rev 34: 471-500

Cathelineau M, Boiron MC, Holliger P, Poty B (1990) Metallogenesis of the French part of the Variscan orogen. Part II: Time-space relationships between U, Au and $\mathrm{Sn}-\mathrm{W}$ ore deposition and geodynamic events - mineralogical and U-Pb data. Tectonophysics 177: 59-79

Chappell BW, White AJR (1974) Two contrasting granite types. Pacific Geol 7: 173-174

Cheilletz A, Archibald DA, Cuney M, Charoy B (1992) ${ }^{40} \mathrm{Ar} /{ }^{39} \mathrm{Ar}$ dating of topaz-lepidolite Beauvoir leucogranite and Chèdeville sodium-lithium pegmatites (North 
Massif Central, France). Petrological and geodynamical meaning. C R Acad Sci Paris 315: 326-336 (in French)

Clark PJ, Evans FC (1954) Distance to nearest neighbor as a measure of spatial relationships in population. Ecology 35: $445-453$

Collective (2008) Minerals of Monts d'Ambazac pegmatites. Special Issue XIV, Le Règne Minéral, Editions du Piat, pp 1-96

Corsini A, Cervi F, Ronchetti F (2009) Weight of evidence and artificial neural networks for potential groundwater spring mapping: an application to the Mt. Modino area (northern Apennines, Italy). Geomorphology 111: 79-87

Cowie PA, Sornette D, Vanneste C (1995) Multifractal scaling properties of a growing fault population. Geophys J Int 122: 457-469

Cuney M, Friedrich M, Blumenfeld P, Bourguignon A, Boiron MC, Vigneresse JL, Poty B (1990) Metallogenesis in the French part of the Variscan orogen. Part I: U preconcentrations in pre-Variscan and Variscan formations - a comparison with $\mathrm{Sn}, \mathrm{W}$ and $\mathrm{Au}$. Tectonophysics 177: $39-57$

Cuney M, Marignac C, Weisbrod A (1992) The Beauvoir topaz-lepidolite albite granite (Massif Central, France): the disseminated magmatic $\mathrm{Sn}-\mathrm{Li}-\mathrm{Ta}-\mathrm{Nb}-\mathrm{Be}$ mineralization. Econ Geol 87: 1766-1794

Cuney M, Alexandrov P, Le Carlier De Veslud C, Cheilletz A, Raimbault L, Ruffet G, Scaillet S (2002) The timing of W-Sn-rare metals mineral deposit formation in the Western Variscan chain in their orogenic setting: the case of the Limousin area (Massif Central, France). In: Blundell DJ, Neubauer F, Von Quadt A(eds) The Timing and Location of Major Ore Deposits in an Evolving Orogen Geological Society London, Special Publications 204: 213-228

ČERNÝ P (1992) Geochemical and petrogenetic features of mineralization in rare-element granitic pegmatites in the light of current research. Appl Geochem 7: 393-416

ČERNÝ P, ERCIT TS (2005) The classification of granitic pegmatites revisited. Canad Mineral 43: 2005-2026

ČERnÝ P, Blevin PL, Cuney M, London D (2005) Graniterelated ore deposits. Econ Geol $100^{\text {th }}$ Anniversary Volume: $337-370$

Demartis M, Pinotti LP, Coniglio Je, D'Eramo FJ, Tubia JM, Aragon E, Agulleiro Insua LA (2011) Ascent and emplacement of pegmatitic melts in a major reverse shear zone (Sierra de Cordoba, Argentina). J Struct Geol: 33, 1334-1346

Dill HG, Š́oda R, Weber B, Berner ZA, Müller A, BakKER RJ (2012) A newly discovered swarm of shear-zonehosted $\mathrm{Bi}-\mathrm{As}-\mathrm{Fe}-\mathrm{Mg}-\mathrm{P}-\mathrm{rich}$ aplites and pegmatites in the Hagendorf-Pleystein Pegmatite Province, southeastern Germany: a step closer to the metamorphic root of pegmatites. Canad Mineral 50: 943-974
ECKLey DC, Curtin KV (2013) Evaluating the spatiotemporal clustering of traffic incidents. Comp Env Urb Sys 37: 70-81

FAure M, Pons J (1991) Crustal thinning recorded by the shape of the Namurian-Westphalian leucogranite in the Variscan belt of the northwest Massif Central, France. Geology 19: 730-733

FelTRIN L (2008) Predictive modelling of prospectivity for $\mathrm{Pb}-\mathrm{Zn}$ deposits in the Lawn Hill Region, Queensland, Australia. Ore Geol Rev 34: 399-427

Flageollet JC, Chantraine J, Ranchin G, Burnol L, MarQuaire C, Gefroy J, Guyonnaud G (1974). Geological map of France, 1:50, 0000, sheet Ambazac (664). BRGM, Orléans

Floc'H JP (1983) Through a branch of the Variscan belt, from Aquitain to Argentat area (French Massif Central). Unpublished Ph.D. thesis, University of Limoges, France (in French)

Friedrich MH, Cuney M, Ротy B (1987) Uranium geochemistry in peraluminous leucogranites. Uranium 3: 353-385

FRY N (1979) Random point distributions and strain measurement in rocks. Tectonophysics 60: 89-105

GöD R (1989) The spodumene deposit at 'Weinebene', Koralpe, Austria. Mineral Depos 24: 270-278

HAASE P (1995) Spatial pattern analysis in ecology based on Ripley's K-function: introduction and methods of edge correction. J Veg Sci 6: 575-582

Holliger P, Cuney M, Friedrich M, Turpin L (1986) Carboniferous age of the Brâme Unit from Saint Sylvestre Peraluminous Granitic Complex (northwestern edge of French Massif Central) defined by $\mathrm{U} / \mathrm{Pb}$ isotopic data on zircon and monazite. C R Acad Sci Paris 303: 1309-1312 (in French)

Hottin A, Delbos R, Pellaton C, Dupuis J, Usnarki G, Marchiol A, Vecsei A (1995) Geological map of France, 1:50 000, sheet Magnac-Laval (640). BRGM, Orléans, (in French)

Kiskowski MA, Hancock JF, Kenworthy AK (2009) On the use of Ripley's K-function and its derivatives to analyze domain size. Biophys J 97: 1095-1103

Knox-Robinson CM, Groves DI (1997) Gold prospectivity mapping using a Geographical Information System (GIS) with examples from Yilgrarn Block of Western Australia. Chron Rech Min 529: 127-138

Knudby A, Ledrew E, Brenning A (2010) Predictive mapping of reef fish species richness, diversity and biomass in Zanzibar using IKONOS imagery and machine-learning techniques. Rem Sens Envir 114: 1230-1241

KONTAK DJ, KySER TK (2009) Nature and origin of an LCTsuite pegmatite with late-stage sodium enrichment, Brazil Lake, Yarmouth County, Nova Scotia. II. Implications of stable isotopes $\left(\delta^{18} \mathrm{O}, \delta \mathrm{D}\right)$ for magma source, internal crystallization and nature of sodium metasomatism. Canad Mineral 47: 745-764. 
Kontak DJ, Creaser RA, Heaman LM, Archibald DA (2005) U-Pb tantalite, Re-Os molybdenite, and ${ }^{40} \mathrm{Ar} /{ }^{39} \mathrm{Ar}$ muscovite dating of the Brazil Lake Pegmatite, Nova Scotia: a possible shear-zone related origin for an LCTtype pegmatite. Atlantic Geol 41: 17-29

LARKin RP, Gumpertz ML, Ristaino JB (1994) Geostatistical analysis of Phytophthora epidemic development in commercial bell pepper fields. Phytopathology 84:191-203

Lima A (2000) Structure, mineralogy and genesis of spodumene aplopegmatitic veins from Barroso-Alvão region. Unpublished Ph.D. thesis, Institut National Polytechnique de Lorraine, Nancy, pp 1-300 (in Portuguese)

London D (2008) Pegmatites. Canad Mineral Special Publications 10: pp 1-347

Mamuse A, Prowal A, Kreuzer O, Beresford S (2010) Spatial statistical analysis of the distribution of komatiite-hosted nickel sulfide deposits in the Kalgoorlie Terrane, Western Australia: clustered or not? Econ Geol 105: 229-242

Marignac C, Cuney M (1999) Ore deposits of the French Massif Central; insight into the metallogenesis of the Variscan collision belt. Miner Depos 34: 472-504

Martins T (2009) Multidisciplinary study of pegmatites and associated $\mathrm{Li}$ and $\mathrm{Sn}-\mathrm{Nb}-\mathrm{Ta}$ mineralization from the Barroso-Alvão region. Unpublished Ph.D. thesis, Universidad do Porto. pp 1-196 (in Portuguese)

Mollier B, Bouchez JL (1982) Magmatic structuring of the Brâme-Saint Sylvestre-Saint Goussaud granitic Complex (Limousin, French Massif Central). C R Acad Sci Paris 294: 1329-1334 (in French)

Mollier B, Lespinasse M (1985) Magmatic and plastic deformation in the northern limit of the Saint Sylvestre granite (northwestern French Massif Central): the Arrènes-Ouzilly Fault. C R Acad Sci Paris 300: 681-686 (in French)

Norton JJ, RedDEn JA (1990) Relations of zoned pegmatites to other pegmatites, granite, and metamorphic rocks, in the southern Black Hills, South Dakota. Amer Miner 75: 631-655

Patureau J (1982) Study of Monts d'Ambazac pegmatites (Margnac, Le Mas Barbu), (Haute-Vienne). Unpublished Ph.D. thesis, University of Paul Sabatier, Toulouse (in French)

Perrier A (1962) Geological guide of Haute-Vienne. Norois 33: 59-61 (in French)

Pollard PJ (1995) A special issue devoted to the geology of rare-metal deposits: an introduction and overview. Econ Geol 90: 489-494

Porwal A, González-Alvarez I, Markwitz V, McCuaig TC, Mamuse A (2010) Weights of evidence and logistic regression modeling of magmatic nickel sulfide prospectivity in the Yilgarn Craton, Western Australia. Ore Geol Rev 38:184-196

Raimbault L (1998) Composition of complex lepidolite-type granitic pegmatites and of constituent columbite-tanta- lite, Chèdeville, Massif Central, France. Canad Mineral 36: 563-583

Raimbault L, Burnol L (1998) The Richemont rhyolite dyke, Massif Central, France: a subvolcanic equivalent of rare-metal granites. Canad Miner 36: 265-282

Ripley BD (1977) Modelling spatial patterns. J Roy Statist Soc B 39: 172-212

Rozas V, Zas R, Solla A(2009) Spatial structure of deciduous forest stands with contrasting human influence in northwest Spain. E J Forest Res 128: 273-285

Scaillet S, Cheilletz A, Cuney M, Farrar E, ArCHIBALD DA (1996) Cooling pattern and mineralization history of the Saint Sylvestre and western Marche leucogranite pluton, French Massif Central: I. ${ }^{40} \mathrm{Ar} /{ }^{39} \mathrm{Ar}$ isotopic constraints. Geochim Cosmochim Acta 60: 4653-4671

Silverman BW (1986) Density Estimation for Statistics and Data Analysis. New York, Chapman and Hall, pp 1-175

Stilling A, ČernÝ P, VAnstone PJ (2006) The Tanco pegmatite at Bernic Lake, Manitoba. XVI. Zonal and bulk compositions ant their petrogenetic significance. Canad Mineral 44: 599623

Sornette A, Davy P, Sornette D (1990) Growth of fractal fault patterns. Phys Rev Lett 65: 2266-2269

Steacy SJ, SAmmis CG (1991) An automaton for fractal patterns of fragmentation. Nature 353: 250-259

Sturges H (1926) The choice of class-interval. J Am Stat Assoc 21: 65-66

TRUEMAN DL, ČERNÝ P (1982) Exploration for rare-element granitic pegmatites. In: ČERNÝ P (ed) Granitic Pegmatites in Science and Industry. Mineralogical Association of Canada Short Course Handbooks 8: pp 463-494

Vaillant M, Jouany JM, Devillers J (1995) A multicriteria estimation of the environmental risk of chemicals with the SIRIS method. Toxicol Model 1: 57-72

VAN LiTCHERVELDE M (2006) Metallogeny of tantalum: application to various types of tantalum mineralization in Tanco pegmatite, Manitoba, Canada. Unpublished Ph.D. Thesis, University of Paul Sabatier, Toulouse, pp 1-294 (in French)

Velde B, Dubois J, Moore D, Touchard G (1991) Fractal patterns of fractures in granites. Earth Planet Sci Lett 104: 25-35

Vidal PH, Griffiths B, Cocherie A, Le Fort P, Peucat JJ, SHEPPARD SMF (1984) Geochemical comparison between Himalayan and Hercynian leucogranites. Phys Earth Planet Inter 35: 179-190

VIEIRA R (2010) Rare-elements aplopegmatites from Almandra (V.N. de Foz-Côa) and Barca d'Alva (Figueira Castelo Rodrigo) regions. Aplopegmatitic field of Fregeneda-Almendra. Unpublished Ph.D. Thesis, Universidad do Porto, pp 1-274 (in Portuguese)

WiLKINS DE, Ford RL (2007) Nearest neighbor methods applied to dune field organization: the Coral Pink Sand Dune, Kane County, Utah, USA. Geomorphology 93: 48-57 